DOI: 10.32089/WBH.PHW.2020.3(273).0001

orcid.org/0000-0002-3515-0688

Janusz Odziemkowski

(Uniwersytet Kardynała Stefana Wyszyńskiego)

\title{
Ewakuacja podczas odwrotu wojsk polskich w okresie czerwiec-sierpień 1920 roku - wybrane zagadnienia
}

Ewakuacja prowadzona w trakcie odwrotu wojsk polskich latem $1920 \mathrm{r}$. jest jednym z najsłabiej opracowanych fragmentów wojny Polski z Rosją bolszewicką. Przeważa pogląd, że mimo popełnionych błędów, a nawet chwil chaosu, była sukcesem strony polskiej i ocaliła wiele zasobów, które ułatwiły przygotowania do bitwy nad Wisłą. Zarówno jej rozmiary, środki użyte do przeprowadzenia, jak i obszar, który objęła, czynią z niej największe bodaj przedsięwzięcie transportowe całej wojny Polski z Rosją bolszewicką. Dokładne prześledzenie przebiegu i efektów ewakuacji wymagałoby obszernej monografii. Niniejszy artykuł, z uwagi na ograniczoną objętość, jest próbą bliższego przedstawienia niektórych jej aspektów i zarysowania obszaru zagadnień wymagających opracowania w przyszłości.

Pierwszy rok wojny z Rosją bolszewicką był pasmem zwycięstw wojsk polskich. Front stale przesuwał się na wschód, a lokalne niepowodzenia powodowały jedynie czasowe wstrzymanie marszu lub przejściowe wycofanie się z niewielkiego terenu. Na północy wojska polskie we wrześniu 1919 r. dotarły do Dźwiny i Berezyny. Przez kolejne dziewięć miesięcy linia frontu polsko-rosyjskiego na Białorusi (rozumianej jako kraina geograficzna) ulegała nieznacznym przesunięciom. Na jej tyłach, na obszarze etapowym - który oddzielał obszar operacyjny (wojenny) przylegający do frontu od obszaru kraju - rozlokowano sieć magazynów, warsztatów, szpitali, ośrodków szkoleniowych, zapasowych, stacji zbornych, urzędów, rozmaitych „urządzeń” niezbędnych dla wojsk etapowych i funkcjonowania zaplecza logistycznego walczących oddziałów. Pracę dla wojska podjęła znaczna liczba lokalnych drobnych firm 
i zakładów rzemieślniczych ${ }^{1}$. Sukcesy armii polskiej ugruntowały zarówno w dowództwach wojskowych, jak i władzach cywilnych przekonanie, że całe rozbudowane, zróżnicowane zaplecze Frontu Litewsko-Białoruskiego jest bezpieczne, a wojna niebawem zakończy się zwycięstwem.

Na południu, po rozbiciu wojsk Zachodnioukraińskiej Republiki Ludowej, oddziały polskie dotarły w lipcu 1919 r. nad Zbrucz i opanowały część Wołynia. W listopadzie, na prośbę rządu Ukraińskiej Republiki Ludowej (URL), wojska polskie wkroczyły do Kamieńca Podolskiego i obsadziły skrawek Podola. W grudniu, kiedy pobita przez bolszewików Armia Ochotnicza gen. Antona Denikina rozpoczęła odwrót, oddziały polskie ruszyły na wschód także na innych odcinkach frontu, zajmując tereny do linii rz. Słucz-Starokonstantynów-rz. Stara Uszyca-Uszyca. Przesunięcie frontu 40-60 km na wschód pociągnęło za sobą analogiczne przesunięcie obszaru etapowego. W efekcie najdalej na wschód wysunięte powiaty Galicji Wschodniej zostały wyłączone z obszaru wojennego i oddane pod kompetencje Dowództwa Okręgu Generalnego (DOGen.) Lwów. W lutym 1920 r. 5 Dywizja Piechoty (DP) gen. Władysława Jędrzejewskiego, za zgodą dowództwa Frontu Podolskiego, przeszła do natarcia na swoim odcinku i odrzuciła nieprzyjaciela za rzeki Wołk i Boh.

Ostatnie większe przesunięcie frontu na południu było efektem ataku na Mozyrz-Kalenkowicze, przeprowadzonego w dniach 4-6 marca 1920 r. przez oddziały Grupy Poleskiej płk. Władysława Sikorskiego. Operacja ta pozwoliła wojskom polskim przerwać ważną strategicznie linię kolejową Petersburg-Orsza-Żłobin-Kalenkowicze-Korosteń, łączącą trzy fronty bolszewickie: Front Północny, Front Zachodni i Front Południowo-Zachodni, a także przerwać styczność operacyjną między oddziałami Armii Czerwonej operującymi na Białorusi i na Ukrainie ${ }^{2}$.

Wiosną 1920 r. Naczelne Dowództwo Wojska Polskiego (NDWP) oraz władze wojskowe i cywilne miały zatem pewne doświadczenie w przemieszczaniu zaplecza w ślad za postępującymi naprzód wojskami i bardzo nikłe w ewakuacji terenów zagrożonych przez nieprzyjaciela. Nie oznacza to, że nie przygotowywano planów ewakuacyjnych. Pierwsze powstały już w maju 1919 r., kiedy nad Rzeczpospolitą zawisła groźba inwazji niemieckiej. W Warszawie poważnie brano pod uwagę możliwość agresji ze strony

\footnotetext{
${ }^{1}$ Szerzej na temat organizacji i funkcjonowania obszaru etapowego zob. J. Odziemkowski, Polskie formacje etapowe na Litwie i Białorusi 1919-1920, Kraków 2011; idem, Polskie formacje etapowe w Galicji Wschodniej, na Wołyniu i Ukrainie w latach 1918-1920, Warszawa 2019. Tam czytelnik odnajdzie również źródła i literaturę.

2 Studia taktyczne z historii wojen polskich 1918-21, t. V: Manewr na Mozyrz i Kalinkowicze 4 III-12 III 1920 r., oprac. J. Ciałowicz, Warszawa 1925, s. 25, 46.
} 
zachodniego sąsiada, gdyby Berlin odmówił podpisania pokoju na warunkach podyktowanych przez mocarstwa Ententy. Położenie Rzeczypospolitej byłoby wówczas niezwykle trudne, ponieważ gros sił polskich angażowały fronty wojen z URL i bolszewicką Rosją. W przypadku ofensywy niemieckiej planowano szybki odwrót za Niemen wojsk Frontu Litewsko-Białoruskiego gen. Stanisława Szeptyckiego, połączony z dokonaniem gruntownych zniszczeń, które miały opóźnić marsz Armii Czerwonej na zachód.

Naczelne Dowództwo rozkazem Nr 295/IVa nakazało przygotowanie do zniszczenia węzłów kolejowych Wilno i Lida, linii kolejowych Wilno-Lida, Wilno-Orany, Grodno-Orany, jak również torów idących z Wilna w kierunku Mołodeczna, Dźwińska i Kowla. Wytypowano do zniszczenia szereg mostów kolejowych i drogowych. Planowano także ewakuację zdobycznych materiałów i taboru kolejowego ${ }^{3}$.

23 maja zapowiedziano rozesłanie materiałów wybuchowych. Do zniszczeń i ewakuacji należało przystąpić dopiero na specjalny rozkaz Dowództwa Frontu Litewsko-Białoruskiego. Berlin ostatecznie podpisał traktat pokojowy i groźba inwazji niemieckiej minęła. Otwarte pozostaje pytanie, czy posiadano dostateczne środki dla wykonania planowanych zniszczeń i wywiezienia zdobyczy wojennej. Armia polska dysponowała wówczas niewielkim zapasem materiałów wybuchowych, wojska saperskie i kolejowe znajdowały się dopiero w stadium formowania (10 maja Ministerstwo Spraw Wojskowych - MSWojsk. - wydało rozkaz op. Nr 510/9 ustalający organizację wojsk saperskich). Na froncie polsko-rosyjskim i polsko-ukraińskim znajdowały się tylko cztery bataliony kolejowe (12 kompanii), nie w pełni jeszcze wyposażone i wyszkolone. Koleje, które w wyniku wojny światowej i rabunkowej polityki okupantów utraciły $75 \%$ taboru ${ }^{4}$, były zbyt obciążone dowozem zaopatrzenia i przegrupowaniami oddziałów na froncie wojny polsko-ukraińskiej, gdzie rozwijała się właśnie polska ofensywa, by wydzielić większą liczbę wagonów na potrzeby Frontu Litewsko-Białoruskiego.

Po ustabilizowaniu frontu, zimą 1919/1920 r. przewidywano możliwości ewakuacji powiatów przyfrontowych w przypadku cofnięcia wojsk spowodowanego lokalnymi niepowodzeniami. Materiał i personel przeznaczony do ewakuacji dzielono na trzy grupy: do pierwszej zaliczono to, co było niezbędne dla wojska i ważne z punktu widzenia funkcjonowania administracji.

\footnotetext{
${ }^{3}$ Centralne Archiwum Wojskowe Wojskowego Biura Historycznego (dalej: CAW-WBH), Wołyńska Inspekcja Etapowa, sygn. I.331.32.1, Dowództwo Litewsko-Białoruskiego Frontu nr 2007/III, Rozkaz przygotowania do zniszczenia linii i węzłów kolejowych na północ od linii Grodno-Lida, b.m. 23 V 1919 r., b.p.

${ }^{4} \mathrm{Na}$ temat strat taboru kolejowego zob. J. Odziemkowski, Polskie kolejnictwo wojskowe na froncie wschodnim 1918-1920, Kraków 2011, s. 41-43, tamże literatura; Polskie Koleje Państwowe 1918-1929, Warszawa 1929; T. Skrzetelski, Polskie koleje Państwowe [w:] Dziesięciolecie Polski Niepodległej, Warszawa 1928.
} 
Obowiązywała zasada, że rozkaz do ewakuacji wydają władze wojskowe i one też kierują jej przebiegiem. Nie rozważano możliwości głębokiego cofnięcia całego frontu i kierowania transportów ewakuacyjnych do centrum kraju za Bug, Niemen i San.

Mimo dużych kłopotów z zaopatrzeniem na wszystkich szczeblach dowodzenia panowały optymizm i wiara we własne siły. Miarą optymizmu był sposób potraktowania ewentualnego zagrożenia ze strony Litwy. Jesienią 1919 r. NDWP poważnie brało pod uwagę możliwość podjęcia przez Litwinów próby opanowania Wilna i Wileńszczyzny, zwłaszcza w przypadku większych walk na froncie polsko-rosyjskim, które związałyby siły polskie. Nie opracowano jednak planu ewakuacji zagrożonych terenów. Przeciwnie, przygotowano operację „Pogoń”, której celem było odparcie agresji i opanowanie Litwy Kowieńskiej. Działania zamierzano przeprowadzić głównie siłami 2 Dywizji Litewsko-Białoruskiej formowanej na Wileńszczyźnie oraz formacji organizowanych w kraju, z niewielkim wsparciem oddziałów frontowych. Kolejnictwo obarczono obowiązkiem dostarczenia 1250 wagonów do transportu wojsk i zaopatrzenia ${ }^{5}$. Do agresji litewskiej jednak nie doszło i operacja „Pogon”" pozostała w sferze projektów.

Również analiza dokumentów dowództw Frontów Wołyńskiego i Podolskiego z zimy 1919/1920 r. prowadzi do wniosku, że nie oczekiwano większego zagrożenia ze strony Armii Czerwonej. Przewidywano, że w przypadku ofensywy bolszewickiej może zajść konieczność cofnięcia frontu na niektórych odcinkach, ale większe obawy budziła w tym czasie możliwość irredenty ukraińskiej na opanowanych terenach Galicji Wschodniej i Wołynia. Wydano szczegółowe instrukcje określające jakie kroki należy podjąć w przypadku wybuchu powstania. Ewakuację terenu dopuszczano tylko w ostateczności; decyzja o jej podjęciu nie leżała w gestii lokalnych władz wojskowych, lecz dowództwa frontu. Słusznie wskazano, że gdyby doszło do wycofywania wojsk, w pierwszej kolejności należy zapewnić ochronę stacjom i liniom kolejowym - od ich sprawnego funkcjonowania zależało powodzenie ewakuacji ludzi i zapasów ${ }^{6}$.

Wyprawę na Kijów, podjętą w kwietniu 1920 r., traktowano jak przejście granicy Rzeczypospolitej i wkroczenie na terytorium zaprzyjaźnionego państwa. Zasady funkcjonowania etapów, linii komunikacyjnych i całego zaplecza armii polskiej na Ukrainie regulowały postanowienia konwencji

\footnotetext{
${ }^{5}$ CAW-WBH, Dowództwo Frontu Litewsko-Białoruskiego, sygn. I.310.3.240, Propozycje szefa kolejnictwa Frontu LB na wypadek „Pogoni”, b.m. 27 X 1919 r., b.p.; sygn. I.310.3.420, Pismo Dowództwa Frontu z 27 października 1919 r., b.m., b.p.

${ }^{6}$ Instrukcje, zarządzenia i dyspozycje w sprawie reakcji wojska na powstanie oraz zasad ewentualnej ewakuacji zob. CAW-WBH, Dowództwo Okręgu Etapowego (dalej: DOE) Podole, sygn. I.331.15.1; DOE Tarnopol, sygn. I.331.20.1 i I.331.20.4; Dowództwo Etapów Wojska Polskiego na Ukrainie, sygn. I.330.1.3.
} 
wojskowej między Polską i URL podpisanej 24 kwietnia 1920 r. Zarząd nad zajętymi przez Polaków terenami na wschód od linii frontu z 24 kwietnia i ochronę tyłów wojsk polskich miały przejmować władze ukraińskie w miarę organizacji władz wojskowych i aparatu administracyjnego niepodległej Ukrainy (URL). Dlatego pozostawiano na stanowiskach miejscowy personel ukraiński. Dowództwo polskie pragnęło jednak zachować kontrolę nad liniami kolejowymi łączącymi z krajem walczące na Ukrainie wojska. Sprawa ta rodziła kontrowersje, o których tak pisał w swoim pamiętniku gen. Jan Romer, dowódca etapów polskich na Ukrainie: „Ukraińcy mocno opierali się tej koncepcji, to ze względów suwerenności, to ze względu na fachowość sił kolejowych (w przeciwieństwie do niefachowości organów wojskowych), to $\mathrm{z}$ powodu różnych nadużyć niższych organów wojskowych polskich, wreszcie ze względu na grożące objawy sabotażu niższego personelu w razie urzeczywistnienia koncepcji polskiej" do czasu rozpoczęcia odwrotu z Ukrainy ${ }^{8}$.

14 maja na Białorusi ruszyła pierwsza ofensywa wojsk Frontu Zachodniego Michaiła Tuchaczewskiego. Jej celem było odciążenie frontu bolszewickiego na Ukrainie i zatarcie zwycięstwami wrażenia, jakie wywarło na opinii publicznej zajęcie Kijowa przez Polaków. Zagrożone zostały Mińsk i Mołodeczno, ważne węzły komunikacyjne na tyłach polskich 1 i 4 Armii. Wymuszony odwrót oddziałów polskich był zaskoczeniem dla ludności oraz administracji cywilnej i wojskowej. Po raz pierwszy podczas wojny z Rosją bolszewicką władze stanęły w obliczu konieczności pospiesznej ewakuacji znacznego obszaru i musiały przeciwdziałać panice, która mogła ewakuację utrudnić. Na tyłach, niejednokrotnie w znacznej odległości od frontu, pojawiły się grupy łazików, dezerterów, rozbitków rozpowszechniających paniczne wieści o klęskach wojsk polskich, podchwytywane i wyolbrzymiane przez komunistów. Wywoływały one niepokój wszystkich, którzy obawiali się powrotu bolszewickiej władzy, bywały przyczyną żywiołowej ewakuacji. Nie wszędzie na wysokości zadania stanęly administracja i policja. W powiatach: lepelskim, dziśnieńskim, nowoaleksandryjskim oraz wilejskim urzędnicy i policjanci pierwsi porzucali pracę i uciekali wraz z rodzinami. Drogi zapełniły tysiące uchodźców wojennych, którzy z dobytkiem podążali na zachód. Odnotowano przypadki bezprawnego zajmowania do celów ewakuacji wagonów kolejowych przeznaczonych do transportu wojska; groziło to chaosem komunikacyjnym i dezorganizowało pracę kolei - 17 DP, skierowana z odwodu Naczelnego Wodza do wzmocnienia 1 Armii, cały dzień

\footnotetext{
${ }^{7}$ J. E. Romer, Pamiętniki, Warszawa 2010, s. 229-230.

${ }^{8}$ J. Odziemkowski, Polskie formacje etapowe w Galicji Wschodniej..., s. 119-120.
} 
czekała na podstawienie pociągów w Wilejce, Mołodecznie, Lidzie i przybyła na front $\mathrm{z}$ dwudziestoczterogodzinnym opóźnieniem99.

$\mathrm{Na}$ nastroje ludności destrukcyjnie wpływał widok masy taborów wojskowych jadących na zachód. Instruktor Straży Kresowej z powiatu święciańskiego pisał w raporcie za maj $1920 \mathrm{r} .:$ „W chwili tej próby na froncie, tak dla nas niespodziewanej, ludność wiejska w olbrzymiej większości z rozpaczą przyglądała się cofającym trenom [taborom - J. O.] polskim i tłumnie ruszała za nimi, porzucając wsie, folwarki i majątki, prowadząc ze sobą bydło i konie. W tej liczbie uchodźców byli ludzie zupełnie ubodzy, których gnał z rodzinnej chaty strach przed głodową śmiercią pod bolszewikami. Ludność nie mogła zrozumieć, że Polacy mogą się cofać przed bolszewikami, wiara w naszą moc była nadzwyczaj silna [...]"10.

Najbardziej dokuczliwy i deprymujący okazał się brak rzetelnej informacji. W raporcie Straży Kresowej powiatu nowogródzkiego za maj czytamy: „Żydzi nie taili swej radości, rozpowszechniali alarmujące pogłoski, że bolszewicy już idą i nadejść muszą - ludność zaś prawosławna podniosła butnie swe rosyjskie głowy, pilnie nasłuchując każdego strzału i wypatrując oczy, czy nie widać cofających się wojsk polskich, a za nimi upragnionych bolszewików. Wobec tego nastrój ludności polskiej był deprymujący, dzienniki rozchwytywano - szły one przez dziesiątki rąk, każdego zaś przybysza z Wilna oblegano wyciągano zeń wszystko i te najnowsze wiadomości leciały lotem błyskawicy po miasteczku raz w południe, innym razem raniutko"11.

Niektórzy dowódcy stacji etapowych codziennie wywieszali spisane na maszynie informacje o położeniu na froncie, aby nie dopuścić do wybuchu paniki.

Dużym zaskoczeniem dla dowództw wojskowych była samorzutna, pospieszna i nieuporządkowana ewakuacja części administracji oraz instytucji cywilnych. Starano się zapanować nad nią, aby nie przeszkadzała transportom na front i wycofywaniu zapasów wojskowych według wcześniej przygotowanych założeń. Oficerowie rozdzielczy w Centralnych Frontowych Stacjach Rozdzielczych (CFSR), których obowiązki polegały na kierowaniu nadchodzących z kraju transportów do miejsc przeznaczenia i zorganizowania przewozu wyładowanych materiałów do magazynów etapowych lub jednostek frontowych, musieli zająć się także regulowaniem przepływu

${ }^{9}$ CAW-WBH, Dowództwo 1 Armii, sygn. I.311.1.130, Pismo Dowództwa 1 armii Oddz. III z 19 maja 1920 do Dowództwa Frontu i Dowództwa 4 armii, b.m., b.p.

${ }^{10}$ Wyciag z raportu powiatu święciańskiego za maj 1920 [w:] O niepodległa i granice, t. 8: Raporty Straży Kresowej 1919-1920 Ziem Pómnocno-Wschodnich opisanie, oprac. J. Gierowska-Kałłaur, Warszawa-Pułtusk 2011 s. 809.

${ }^{11}$ 1920, maj 27, Nowogródek, wyciąg z raportu Straży kresowej powiatu nowogródzkiego za maj 1920 [w:] ibidem, s. 681. 
transportów ewakuacyjnych w taki sposób, aby nie powodowały zakłóceń w przewozach wojska ${ }^{12}$. Rzadka sieć kolejowa na terenach wschodnich, z przewagą linii jednotorowych o małej przepustowości, czyniła to zadanie niełatwym. Aby mu podołać, oficerowie rozdzielczy starali się utrzymywać kontakt z dowódcami dworców i oficerami łącznikowymi kolei. Jednak przerwy w łączności powodowały opóźnienia w przekazywaniu informacji o pociągach zdążających na stacje rozdzielcze.

23 maja dowództwo 4 Armii wydało rozkaz przygotowania w podległym mu okręgu etapowym ewakuacji pierwszej grupy. Zaliczono do niej: chorych i rannych żołnierzy, zapasową broń, amunicję, ruchome warsztaty artyleryjskie i samochodowe, kasę operacyjną armii, cały zapas umundurowania i prowiantu z wyjątkiem dziesięciodniowej racji dla oddziałów. Materiał artyleryjski miał trafić do Leśnej ${ }^{13}$, ranni i chorzy do Lublina, zbędne maszyny i materiał kolejowy do Brześcia Litewskiego, pozostałe zapasy do Baranowicz. W ramach pierwszej grupy przygotowano także ewakuację zapasów pieniędzy, kruszców i dokumentów Zarządu Cywilnego Ziem Wschodnich, banków, poczt i Czerwonego Krzyża. Ewakuację zakładów i magazynów położonych na wschód od Mińska należało rozpocząć bezzwłocznie, z pozostałych terenów - po otrzymaniu odrębnego rozkazu. Transporty kierowane z kraju do 4 Armii, z uwagi na zagrożenie jej obszaru etapowego, należało skierować, zależnie od ładunku, do Brześcia Litewskiego, Leśnej lub Baranowicz. Aby nie dopuścić do zablokowania linii kolejowych, oficer rozdzielczy 4 Armii skierował transporty ewakuacyjne instytucji cywilnych i uchodźców jadące z zagrożonego przez Armię Czerwoną starostwa Borysów na linię Borysów-Baranowicze, a transporty ze starostw Ilhumeń i Puchowicze na linię Ilhumeń-Żabinka (k. Brześcia Litewskiego) ${ }^{14}$.

Do zadań priorytetowych zaliczono ewakuację nadającego się do użytku taboru kolejowego. Zabierano tabor szeroko-, jak i normalnotorowy, a także wąskotorówki. Kompanie IV i VIII Batalionu Kolejowego ewakuowały kolejkę

${ }^{12}$ Centralne Frontowe Stacje Rozdzielcze (CFSR) organizowano od lata 1919 r. do lutego 1920 r., a oficerów rozdzielczych przy CFSR wyznaczano od listopada 1919 r., zob. CAW-WBH, Dowództwo Frontu Wołyńskiego, sygn. I.310.18.106, Rozkaz NDWP/Sztab Generalny nr 49418/IV z 1 XI 1919 r., Zorganizowanie regularnego dowozu dla zaopatrywania frontu. Centralne Frontowe Stacje Rozdzielcze. Oficerowie rozdzielczy, b.m., b.p.; Dowództwo 6 Armii, sygn. I.311.6.286, Instrukcja dla oficerów rozdzielczych przy Centralnych Frontowych Stacjach Rozdzielczych, Zał. Nr 1 do rozkazu Naczelnego Dowództwa Nr 49418/IV, b.m., b.d., b.p.

${ }^{13}$ Leśna, miejscowość i stacja na linii kolejowej Baranowicze-Brześć Litewski, w 1920 r. kilkakrotnie rejon walk oddziałów polskich z Armią Czerwoną

${ }^{14}$ CAW-WBH, Dowództwo 4 Armii, sygn. I.311.4.464, Dowództwo 4 Armii do oficera rozdzielczego armii, b.m., b.d., b.p.; Depesza dowództwa 4 Armii z 22 V 1920. Ewakuacja starostw Borysów, Ilhumeń, Puchowicze, b.m. 23 V 1920 r., b.p.; Dowództwo 4 Armii 23 V 1920. Ewakuacja przygotowawcza, b.m., b.p. 
Parafianowo-Berezyna i kolej Turmont-Mołodeczno „[...] nie zostawiając na tej linii ani jednego wozu kolejowego"15. Kompanie kolejowe dokonywały także zniszczeń na stacjach opuszczanych przez wojsko i zrywały torowiska.

W drugiej grupie ewakuowano zakłady i urządzenia tyłowe 1 i 4 Armii. Jako zachodnią granicę, do której dopuszczalne było rozmieszczanie ewakuowanych dóbr, wyznaczono linię kolejową Łuniniec-Baranowicze-Wołkowysk-Białystok.

Wagony dla ewakuacji przydzielała CFSR 4 Armii w Mińsku Litewskim, w porozumieniu z szefem kolejnictwa wojskowego. Natomiast przebiegiem ewakuacji kierowało Dowództwo Okręgu Etapowego (DOE) Mińsk, które dostarczało eskorty dla pociągów i wyznaczało komendantów transportów. Obliczono, że tylko do wywiezienia zapasów aprowizacyjnych z terenów na wschód od Mińska trzeba będzie podstawić: do Mołczadzi - 98, do Żabinki - 108, do Rudzieńska - 4 wagony, łącznie - 210 wagonów ${ }^{16}$.

Po 25 maja ofensywa wojsk Tuchaczewskiego zaczęła tracić impet i została zatrzymana na linii Ziembin-rz. Ilia-rz. Serwecz-Krzywicze-Stary Miadzioł-jezioro Bohin-jezioro Dryświaty. Kontrofensywę polską rozpoczęły 31 maja wojska 1 Armii. 2 czerwca ruszyło uderzenie Armii Rezerwowej gen. Kazimierza Sosnkowskiego. Ewakuacja zagrożonych powiatów została wstrzymana, ale pociągi ewakuacyjne już załadowane wyprawiano w drogę do miejsc przeznaczenia. Dopiero kiedy stwierdzono na wszystkich odcinkach pospieszny odwrót Armii Czerwonej, 4 czerwca NDWP wydało rozkaz natychmiastowego zaprzestania ewakuacji i przywrócenia obszaru tyłowego armii do stanu sprzed ofensywy nieprzyjaciela ${ }^{17}$.

6 czerwca uruchomiono proces powrotu ludzi i materiałów do miejsc, z których zostały zabrane. Reewakuacja trwała ponad dwa tygodnie - opóźniał ją niedostatek taboru kolejowego zaangażowanego do przerzutu wojsk na Ukrainę, gdzie starano się osaczyć 1 Armię Konną i zatrzymać ofensywę bolszewicką. Porządkowanie tyłów 1 Armii wraz z naprawą zniszczonych linii i mostów kolejowych, przywróceniem regularnych kursów pociągów osobowych, pocztowych i sanitarnych na obszarze etapowym ukończono w trzeciej dekadzie czerwca ${ }^{18}$.

\footnotetext{
${ }^{15}$ J. Wyporek, Zarys historii wojennej 2-go pułku wojsk kolejowych, Warszawa 1930.

${ }^{16}$ CAW-WBH, Dowództwo 4 Armii, sygn. I.311.4.464, Pismo gen. Mieczysława Norwida-Neugebauera kwatermistrza 4 Armii do szefostwa kolejnictwa 4 Armii z 24 V 1920 r. w sprawie wagonów do wywiezienia zapasów aprowizacyjnych, b.m., b.p.

${ }^{17}$ CAW-WBH, Kolekcja Rękopisów, sygn. I.400.824, NDWP/SGen. Służba rozdzielcza na obszarze 4, 1, Rezerwowej i 7 armii, b.m. 4 VI 1920 r., b.p.

${ }^{18}$ Szczegółowo przedstawia to Organizacja służb zaopatrzenia materialnego i etapów 1 Armii z 28 VI 1920 r. Ciekawostką jest wprowadzenie codziennego kursowania „pociągu zbiorowego", który zbierał starą lub uszkodzoną broń, drut kolczasty, łuski itp. materiały użyteczne dla przemysłu krajowego, zob. CAW-WBH, Dowództwo 1 Armii, sygn. I.311.1.130.
} 
Przebieg wydarzeń dostarczył materiału do oceny opracowanego przez polskie dowództwo systemu ewakuacji - wskazał jego słabe punkty, zaniedbania i popełnione błędy. Przede wszystkim zaś uświadomił istnienie zagrożeń i możliwą skalę ewakuacji w przypadku nowej ofensywy nieprzyjaciela. Ewakuacja i reewakuacja prowadzone na Białorusi w maju-czerwcu $1920 \mathrm{r}$. jak dotąd nie doczekały się opracowania w polskiej historiografii.

Polski front na Ukrainie został osłabiony poprzez odesłanie w drugiej połowie maja kilku jednostek do walki z Tuchaczewskim na Białorusi. Były to: 4 i 15 DP oraz IX Brygada Piechoty (BP) i III/40 Pułku Piechoty ze składu 5 DP. Do transportu tych wojsk zabrano część taboru kolejowego obsługującego front ukraiński, co spowodowało między innymi czasowe ograniczenie kursowania pociągów aprowizacyjnych. Kiedy walki przeciwko Tuchaczewskiemu dobiegały końca, na Ukrainie 1 Armia Konna Siemiona Budionnego, po dwóch nieudanych próbach przerwania frontu polskiego, przełamała 5 czerwca obronę słabej grupy gen. Jana Sawickiego pod Samhorodkiem i ruszyła na Koziatyn, dokonując równocześnie zagonów 4 Dywizją Kawalerii (DK) na Żytomierz i 11 DK na Berdyczów. Masy ruchliwej jazdy zdawały się być wszędzie. Zaskoczenie i niedostatki łączności, sprzyjające szerzeniu alarmistycznych plotek, spowodowały wiele zamieszania i niepewności na tyłach frontu. Naczelny Wódz nakazał skierowanie na Ukrainę 3 DPLeg., 6 DP i 16 DP. Z uwagi na ówczesne możliwości polskiego kolejnictwa i przepustowość linii kolejowych transport wojsk musiał potrwać co najmniej kilka dni. W tej sytuacji Józef Piłsudski wydał 8 czerwca rozkaz ewakuacji Kijowa i cofnięcia 3 Armii na Teterew, celem szybszego jej połączenia z nadciągającymi posiłkami i podjęcia skoordynowanych działań przeciwko Budionnemu. 10 czerwca wojska polskie opuściły stolicę Ukrainy i rozpoczęły odwrót. Wiązał się on z koniecznością zapewnienia możliwości wyjazdu rządowi ukraińskiemu, misjom zagranicznym, miejscowym Polakom, którzy słusznie obawiali się powrotu władzy bolszewickiej, ewakuacji zgromadzonych w Kijowie zakładów armii, zapasów, warsztatów, taboru kolejowego i motorowego.

Głównej kolumnie 3 Armii cofającej się wzdłuż torów linii Kijów-Korosteń towarzyszył ogromny tabor konny i ponad dwudziestokilometrowa kolumna, w której jechało 26 transportów kolejowych. 3 Polowy Dywizjon Samochodowy, dysponujący ponad setką pojazdów motorowych, otrzymał rozkaz dołączenia do taborów konnych. Taka decyzja świadczyła, że podejmujący ją oficer miał niewielkie pojęcie o warunkach eksploatacji i możliwościach taboru motorowego. Pozbawiała dywizjon jego głównego atutu - ruchliwości, groziła wielkim zużyciem paliwa, silników, nawet utratą cennego sprzętu. Interwencje podejmowane przez dowódcę dywizjonu kpt. Alfreda Schmidta rozbijały się o mur niekompetencji. Według relacji dowódcy dywizjonu, kiedy samochody stały już w kolumnie wozów konnych, pojawił się dowódca 
3 Armii gen. Edward Śmigły-Rydz. Kapitan Schmidt wykorzystał szansę, zameldował się u generała i przedstawił swoje obiekcje. Dowódca armii polecił mu ruszać natychmiast do Żytomierza, nie czekając na tabory konne. W ciągu dwóch dni dywizjon pokonał trasę Kijów-Żytomierz-Równe, tracąc po drodze tylko cztery maszyny znajdujące się w najgorszym stanie technicznym. Długa kolumna samochodów była obserwowana przez jazdę bolszewicką, która jednak nie odważyła się jej zaatakować ${ }^{19}$. Z dużym prawdopodobieństwem decyzja gen. Śmigłego-Rydza ocaliła 3 Dywizjon Samochodowy. Wszystkie pozostawione do dyspozycji 3 Armii maszyny (35 samochodów osobowych i ciężarowych, 3 sanitarki, samochód cysterna i motocykl) przepadły na szlakach odwrotu ${ }^{20}$.

Zasadnicze znaczenie dla powodzenia ewakuacji Kijowa miała bitwa pod Borodzianką stoczona 11-13 czerwca 1920 r. nad rzeką Zdwiż, około $50 \mathrm{~km}$ na zachód od stolicy Ukrainy. Nad Zdwiżem zajęły stanowiska: 73 Brygada Strzelecka (BS) i jeden pułk 75 BS ze składu 25 Dywizji Strzeleckiej (DS), wspierane przez część 7 DS i Baszkirskiej Brygady Jazdy. Most kolejowy na Zdwiżu był jedyną drogą przejazdu na zachód dla pociągów towarzyszących 3 Armii. Nieprzyjaciel zerwał szyny, ale nie zdążył zniszczyć samego mostu. Do południa 12 czerwca, po zaciętych walkach 1 DPLeg. opanowała most i odrzuciła oddziały Armii Czerwonej. Saperzy natychmiast przystąpili do pracy nad naprawą torów. O godz. 18 mostem ruszyła na zachód kolumna transportów ewakuacyjnych prowadzona przez pociąg pancerny „Paderewski”. Po jej przejeździe saperzy zniszczyli most na Zdwiżu. Zwycięstwo pod Borodzianką zakończyło najtrudniejszą część walk odwrotowych 3 Armii ${ }^{21}$.

Wraz z wojskiem Kijów opuściły tysiące mieszkających tam lub czasowo przebywających rodzin polskich. Większość znalazła miejsce w pociągach ewakuacyjnych, część jechała wozami konnymi. Niestety, na tym etapie badań nie da się precyzyjnie określić, jaką liczbę uchodźców i jaki materiał wywieziono z Kijowa. Być może dokładna analiza meldunków sytuacyjnych i raportów sytuacyjnych szefów kolejnictwa 2 i 3 Armii przyniosłaby więcej informacji, przynajmniej na temat wywiezionego majątku wojskowego.

O ile 3 Armia radziła sobie dobrze podczas pierwszej fazy odwrotu znad Dniepru, o tyle alarmujące wieści napływające $\mathrm{z}$ frontu i brak rzetelnej informacji wywołały wybuch paniki na polskich tyłach. Analiza dokumentów

\footnotetext{
${ }^{19}$ CAW-WBH, Kolekcja rękopisów, I.400.1041, Kpt. Alfred Schmidt, „Odwrót polowego dyonu samochodowego nr 3 spod Kijowa w czerwcu 1920 r.", mps.

${ }^{20}$ CAW-WBH, Oddział IV NDWP, sygn. I.301.10.285, Lista strat 1 i 3 Armii z 23 VI 1920 r., b.m., b.d., b.p.

${ }^{21}$ O przebiegu i znaczeniu bitwy pod Borodzianką m.in. A. Borkiewicz, Dzieje 1-go pułku piechoty Legionów, Warszawa 1929; А. Протопопов, Отход 3 польской армии от Киева в июне 1920 года, „Война и революция” 1929, nr 7-8.
} 
wskazuje, że była ona głębsza i bardziej destrukcyjna od tej, która kilka tygodni wcześniej ogarnęła zaplecze frontu na Białorusi. Być może przyczyna leżała w tym, że na Białorusi obszar etapowy był już mocno zakorzeniony i utrwalony na tyłach polskiego frontu. Ponadto opanowane tereny białoruskie uważano za część Rzeczypospolitej, natomiast polskie etapy na Ukrainie działały na terytorium obcego państwa, znajdowały się w trakcie organizacji, stykały na co dzień nie z polską, lecz ukraińską administracją cywilną i kolejową, przeważnie obojętną lub niechętną, czasem otwarcie wrogą wobec Polaków.

Panika spowodowała chaotyczną, pospieszną ewakuację. Formacje tyłowe, służby, urzędy wojskowe zajmowały stojące na dworcach wagony, które wypełniano sprzętem, jaki był pod ręką; zdarzało się, że ładowano wyposażenie biurowe, pozostawiając zapas amunicji. Rekwirowano parowozy i wymuszano na kolejarzach skierowanie pospiesznie zestawianych transportów do węzłów komunikacyjnych na dalekich tyłach. Żywiołowy ruch pociągów mógł grozić zablokowaniem nielicznych szlaków komunikacyjnych. Stanisław Lis-Błoński, świadek ewakuacji Winnicy zarządzonej 9 czerwca przez gen. Jana Romera, zanotował w pamiętniku: „Kto tylko zdążył, zabierał co mógł bodaj do podręcznych walizeczek i wraz z wojskiem ładował się do przepełnionych wagonów osobowych i towarowych byleby tylko się wydostać z Winnicy. Był to przerażający widok, ta nagła, nie przewidziana ewakuacja. Nikt nie zatroszczył się o społeczeństwo polskie Winnicy. O rodziny tych, którzy gościli u siebie oficerów, o tych, którzy prowadzili pracę społeczną na rzecz polskości, pracę oświatową i opieki nad żołnierzem"22.

Nawet doświadczony i opanowany dowódca frontowy, wysoko ceniony przez Naczelnego Wodza, dał się porwać chaosowi odwrotu. Dopiero po przybyciu do Klewania gen. Romer ochłonął i wysłał do Winnicy Lisa-Błońskiego z pięcioma żołnierzami, aby nawiązali kontakt z 18 DP, która miała cofać się przez to miasto, i przekazywali meldunki o położeniu. Grupka dowodzona przez Lisa-Błońskiego pozostała w Winnicy do wieczora 13 czerwca, nie niepokojona przez nieprzyjaciela. Na linii Winnica-Żmerynka przez cały ten czas kursowały pociągi; wszystkie odchodziły wypełnione do ostatniego miejsca ludnością uciekającą przed bolszewikami. Na zachód ruszyły pieszo lub wozami konnymi rodziny obawiające się powrotu władzy bolszewickiej, zabierając ze sobą część dobytku. Lis-Błoński osobiście namówił do powrotu do domu właściciela ziemskiego, który zmierzał na zachód, prowadząc ze sobą cały inwentarz, przekonując go, że ucieczka nie ma sensu. Prawdopodobnie sam nabrał błędnego przekonania, że sytuacja na froncie ustabilizowała się ${ }^{23}$. Niezależnie od motywów, jakimi kierował się wspomniany oficer, gdyby nie

${ }^{22}$ S. Lis-Błoński, Pięćdziesiąt dni na Podolu w 1920 r., „Niepodległość” 1939, t. XX, z. 2 (55), s. 324 .

${ }^{23}$ Ibidem, s. 328-333. 
wybuch paniki, władze etapowe mogłyby urzędować w Winnicy jeszcze kilka dni, organizując w uporządkowany sposób ewakuację majątku należącego do armii oraz wyjazd ludności cywilnej, zwłaszcza rodzin polskich, które pomagały wojsku.

Kiedy minęły pierwsze dni zaskoczenia, chaos udało się opanować. Powolny odwrót wojsk z Ukrainy, przerywany próbami ustabilizowania frontu i osaczenia Armii Konnej, sprzyjał uporządkowaniu ewakuacji. Saperzy w szybkim tempie odbudowali zniszczone przez nieprzyjaciela mosty kolejowe na rzekach Roś i Rastawica, co umożliwiło m.in. wycofanie dwóch pociągów pancernych i sporej liczby taboru szerokotorowego, w ówczesnych warunkach jedynego środka szybkiego transportu na Ukrainie ${ }^{24}$. Starano się także, w miarę możności, wywozić cenniejsze urządzenia stacji i parowozowni. Ewakuacja majątku kolejowego nie była wcześniej planowana, jako że całe kolejnictwo przejąć miały władze URL. Teraz pełniła dwojaką rolę: ratowała tabor i sprzęt potrzebny kolejom polskim, nieprzyjacielowi zaś utrudniała uruchomienie transportu kolejowego na zdobytych terenach. Zabierano nie z góry wyselekcjonowane maszyny, narzędzia, sprzęt łączności, ale to, co w danej chwili osoby prowadzące ewakuację uznawały za najbardziej przydatne. Dokonywano też zniszczeń na opuszczanych stacjach, zrywano tory i rozjazdy, wysadzano wieże ciśnień, mosty kolejowe i drogowe. Zniszczenia te były na tyle rozległe, że według ustaleń wywiadu polskiego jeszcze w końcu sierpnia bolszewicy nie zdołali usunąć wszystkich szkód.

Most pod Cudnowem, który 7 kompania kolejowa oddała do użytku 12 czerwca, już w trakcie odwrotu z Ukrainy umożliwił ewakuowanie do Szepietówki dużej liczby wagonów i parowozów. Po przejeździe ostatniego transportu saperzy wysadzili most w powietrze, a następnie cofali się z frontem, ewakuując i niszcząc stacje i tory na linii Cudnów-Szepietówka. 6 kompania kolejowa robiła to samo na linii Winnica-Płoskirów-Szepietówka, a 8 kompania na linii Chwastów-Biała Cerkiew. 19 czerwca NDWP nakazało przeniesienie Wojskowej Dyrekcji Kolejowej ${ }^{25} \mathrm{z}$ Żytomierza do Tarnopola i powierzyło jej między innymi inwentaryzowanie i zabezpieczenie ewakuowanego taboru oraz materiału kolejowego w porozumieniu z Dyrekcją PKP w Równem i innymi sąsiednimi dyrekcjami kolei. Dyrekcja miała także

${ }^{24}$ W. Michalczyk, Zarys historii wojennej 1-go pułku saperów kolejowych, Warszawa 1931, s. 52.

${ }^{25}$ Wojskowa Dyrekcja Kolejowa została utworzona na krótko przed odwrotem wojsk polskich. Miała uporządkować kolejnictwo ukraińskie. Składała się z personelu polskiego i ukraińskiego, pracowała pod komendą polską i podlegała NDWP przez ekspozyturę szefa kolejnictwa wojskowego na Ukrainie. CAW-WBH, Dowództwo Etapu Wojska Polskiego Lwów, sygn. I.330.3.1, NDWP /Sztab Generalny/, Pismo z 19 VI 1920 r. do Wojskowej Dyrekcji Kolejowej, b.m., b.p.; J. Romer, Pamiętniki..., s. 329-330. 
administrować kolejami funkcjonującymi na terenach Ukrainy pozostającymi w rękach wojsk polskich i sojuszniczej armii Symona Petlury ${ }^{26}$.

Do cofającego się wojska dołączały bataliony etapowe osłaniające obszar etapowy armii. W ten sposób, nie posiadając wyszkolenia i wyposażenia pozwalającego na podjęcie walki z formacjami Armii Czerwonej, korzystały podczas odwrotu z osłony oddziałów frontowych. Natomiast DOE na Ukrainie, wraz z wyposażeniem, były ewakuowane transportem kolejowym i konnym ${ }^{27}$.

Ewakuacja na Ukrainie przebiegała etapami. Zatrzymywanie wojsk frontowych na kolejnych liniach obrony i podejmowane przez polskie dowództwo próby rozbicia 1 Armii Konnej powodowały czasowe wstrzymanie ewakuacji w nadziei na stabilizację frontu. Dopiero w końcu czerwca wydano zarządzenia przewidujące odwrót za rzekę $\mathrm{Zbrucz}^{28}$.

$\mathrm{Na}$ przełomie czerwca i lipca linie kolejowe prowadzące na zachód były zapchane transportami ewakuacyjnymi. Formacje wojsk kolejowych starały się zwiększyć ich przepustowość, aby umożliwić przejazd oczekującym w długich kolejkach eszelonom. Fragmenty historii 5 kompanii II Batalionu Kolejowego dowodzonej przez kpt. Gustawa Jenknera ukazują warunki, w jakich przebiegała wówczas ewakuacja. W pierwszych dniach lipca kompania otrzymała rozkaz przeprowadzenia ewakuacji stacji Zdołbunów. Część żołnierzy, pod kierunkiem oficerów, przystąpiła do rozmontowania i załadunku na platformy urządzeń warsztatów kolejowych, w których wykonywane były remonty parowozów. Ewakuacja trwała bez przerwy w dzień i w nocy, przy odgłosach zbliżającego się frontu. Z załadowanych platform zestawiano składy pociągów, które jeden za drugim odjeżdżały w stronę Równego.

Reszta kompanii, przy pomocy miejscowych kolejarzy, starała się opróżnić stację ze stojących tam transportów, aby umożliwić przejazd przez Zdołbunów masie pociągów nadjeżdżających ze wschodu, które zalegały na torach w wielokilometrowej kolejce przed Zdołbunowem. Były wśród nich cywilne transporty ewakuacyjne, czołówki sanitarne, prowiantowe, amunicyjne i urzędy gospodarcze dywizji, tabory pociągów pancernych ${ }^{29}$. Na bocznicach

${ }^{26}$ CAW-WBH, Dowództwo Etapów Wojska Polskiego Lwów, sygn. I.330.3.1, Odpis depeszy NDWP /Sztab Gen./ z 19 VI 1920 r. do Dowództwa Etapów Wojska Polskiego, Starokonstantynów, b.p.

${ }^{27} \mathrm{O}$ ewakuacji etapów i sposobie wykorzystania wojsk etapowych podczas odwrotu i ewakuacji zob. J. Odziemkowski, Polskie formacje etapowe w Galicji Wschodniej..., s. 131-142. Tam też źródła i literatura.

${ }^{28}$ CAW-WBH, DOE Kowel, sygn. I.331.9.12, Zarządzenie na wypadek ewentualnego odwrotu za Zbrucz, DOE Płoskirów 30 VI 1920 r., b.p.

${ }^{29}$ Pociąg pancerny składał się z części bojowej - opancerzonych i uzbrojonych wagonów i lokomotywy opancerzonej, oraz części taborowej - wagonów kolejowych towarowych, 
w Zdołbunowie stało wiele wagonów pustych, oczekujących na załadunek, oraz parowozów uszkodzonych i pod parą ${ }^{30}$.

W nocy z 3 na 4 lipca na stację przybył oficer ułanów z meldunkiem, że bolszewicy zdobyli most pod pobliskim Ożeninem i niedługo mogą pojawić się w Zdołbunowie. Porucznik Kowalski natychmiast ogłosił alarm w batalionie. Zbliżanie się nieprzyjaciela zasygnalizowała potężniejąca strzelanina, na stację zaczęły spadać pociski rosyjskiej artylerii. Jeden trafił w wagon $\mathrm{z}$ amunicją; wówczas plutonowy Szeguła ${ }^{31}$ odczepił parowóz od płonącego wagonu i odjechał, ratując cenną lokomotywę. Rozpoczął się wyścig z czasem: walczące oddziały powstrzymywały natarcie przeciwnika, a żołnierze por. Kowalskiego pracowali, aby ocalić ewakuowanych, nie dopuścić do straty taboru kolejowego i cennego ładunku. Autor historii wojennej 1 Pułku Saperów zanotował: „Nad ranem 4 lipca wszystkie transporty zdołano odesłać do Równego i kompania ze swym taborem podążyła jako ostatnia, przy czym do pociągu kompanii kolejowej doczepiono jeszcze pluton żandarmerii polowej [tj. wagon wiozący pluton żandarmerii - J. O.]"32.

Po przybyciu do Równego II Batalion Kolejowy otrzymał rozkaz niezwłocznego ewakuowania pociągów stojących na stacji i na bocznicach. Powtórzyła się sytuacja ze Zdołbunowa. Przy wzmagających się odgłosach strzelaniny $\mathrm{z}$ coraz bliższego frontu kompanie batalionu przystąpiły do rozładowania zatorów. Pociągi wysyłano w dwóch kierunkach: do Klewania i do Aleksandrii. Kiedy po całym dniu ciężkiej pracy w wielkim lipcowym upale udało się wszystkie transporty wyekspediować, nadszedł meldunek, że most pod Klewaniem jest uszkodzony i pociągi ponownie utknęły. Szczęśliwie na stacji w Zdołbunowie żołnierze znaleźli dwie platformy z dźwigami mostowymi. Platformy doczepiono z przodu i z tyłu parowozu, po czym 2 i 5 kompanie II Batalionu załadowały się do zaimprowizowanego pociągu, który wieczorem wyjechał ze Zdołbunowa. Na wypadek napotkania nieprzyjaciela na platformach ustawiono sześć ciężkich karabinów maszynowych. Ostrożność okazała się zbędna, ponieważ po drodze napotkano kolumny 3 DPLeg. cofające się wzdłuż toru. Po dotarciu na miejsce saperzy naprawili uszkodzenia mostu i zatrzymane transporty mogły ruszyć dalej ${ }^{33}$.

Najbardziej niebezpieczne dla przebiegu ewakuacji okazały się zagony jazdy bolszewickiej na polskie tyły. Transporty ewakuacyjne i zatłoczone

czasem 1-2-osobowych dla kadry, nieopancerzonych, wiozących narzędzia do naprawy sprzętu kolejowego i torów, amunicję, żywność itp.

${ }^{30}$ W. Michalczyk, Zarys historii wojennej 1-go pułku saperów..., s. 53.

${ }^{31}$ Imienia nie ustalono.

${ }^{32}$ W. Michalczyk, Zarys historii wojennej 1-go pułku saperów..., s. 54.

${ }^{33}$ Ibidem, s. 55. 
stacje kolejowe były praktycznie bezbronne wobec jej ataków, a osłona, jaką mogły zapewnić szczupłe oddziały etapowe i nieliczne eskorty pociągów, była daleko niewystarczająca. Możliwości jazdy bolszewickiej pokazał zagon 8 DK Czerwonego Kozactwa na tyły polskiej 6 Armii, który opanował 5 lipca stację Jarmolińce, plądrując 80 wagonów, zrywając tory i niszcząc urządzenia stacyjne. Następnie Kozacy zajęli Czarny Ostrów, gdzie wycięli kilkuset żołnierzy z oddz. tyłowych, zniszczyli ukr. pociąg sztabowy. Strona polska poniosła znaczne straty, niebezpieczne okazało się jednak zablokowanie linii kolejowej, na której utknęło kilka transportów ewakuacyjnych; było kwestią czasu, kiedy wpadną w ręce nadciągającej Armii Czerwonej. Po wycofaniu się Kozaków szef kolejnictwa 6 Armii kpt. inż. Władysław Gallas wydał I Batalionowi Kolejowemu rozkaz odblokowania torów. Do Czarnego Ostrowa udały się dwie kompanie kolejowe. Pracowano pod osłoną ustawionych na lorach pociągu budowlanego ciężkich karabinów maszynowych i ukraińskiego pociągu pancernego „Karmeluk”. „Podnoszono wóz za wozem, szarpano linami, spychano z nasypu. Pękały liny konopne, sprowadzono stalowe, ale ludzie nie spoczęli ani chwili, mimo że słońce paliło niemiłosiernie. Wreszcie sprowadzono też pomoc cywilną. Zebrano kilkaset chłopów i wieśniaczek do lin i rozkopywano dalej górę drzewa i żelaza na moście. Po południu na miejsce robót przyjechał gen. Romer i naglił do pośpiechu, więc też ludzie dobywali resztek sił byle tylko robota nie stanęła” 34 . „Karmeluk” pomagał, spychając z nasypu rozbite wagony. Przed wieczorem 8 lipca tor był wolny i czekające transporty mogły kontynuować podróż.

Zator kolejowy był przyczyną utraty dużej części taboru szerokotorowego używanego na odcinku polskiej 6 Armii. Pociągi dojechały bez przeszkód do Płoskirowa, a stąd, jedyną linią szerokotorową, próbowały dotrzeć do Szepietówki. Utknęły jednak w wielkim zatorze kolejowym i w większości wpadły w ręce Armii Czerwonej. Powiodła się natomiast ewakuacja taboru, który przez Zdołbunów skierowano do Lwowa. Tą drogą do miasta nad Pełtwią dotarło z Ukrainy łącznie 20 parowozów, 1500 wagonów towarowych i 175 osobowych. Ocalał także tabor wysłany do Kowla, który przez Brześć nad Bugiem dojechał do Dęblina. Wywiezienie dużej liczby parowozów i wagonów z Ukrainy było możliwe dzięki pracy kompanii wojsk kolejowych, które sprawnie poszerzyły („przeszyły”) tor o „europejskim rozstawie” szyn do wymiarów „szerokiego” toru rosyjskiego na odcinku Brześć-Dęblin ${ }^{35}$.

W połowie lipca wojska polskie obsadziły linię rz. Zbrucz, na której zamierzono zatrzymać nieprzyjaciela i uchronić Galicję od inwazji Armii Czerwonej.

\footnotetext{
${ }^{34}$ Ibidem, s. 43. Zob. także T. Grzegorczyk, 6 Armia Wojska Polskiego w 1920 r., Toruń 2009, s. 204-208.

${ }^{35}$ J. Odziemkowski, Polskie kolejnictwo wojskowe..., s. 70.
} 
Oceniając przebieg ewakuacji prowadzonej podczas odwrotu wojsk polskich na Ukrainie, należy stwierdzić, że nie została ona zawczasu należycie przygotowana, była zaskoczeniem dla dowództwa i formacji tyłowych armii, a jej początek przebiegał wśród oznak chaosu i paniki. Niejednokrotnie, zwłaszcza w pierwszym stadium odwrotu, trzeba było uciekać się do improwizacji pod silną presją nieprzyjaciela. Niemniej odwrót z Kijowa nad Zbrucz trwał ponad pięć tygodni. Było więc sporo czasu na zabranie zapasów, majątku wojskowego, zdobyczy wojennej, wielu cennych urządzeń stacyjnych i dużej części szerokotorowego taboru kolejowego.

Nie pomyślano jednak o zapewnieniu możliwości wyjazdu polskiej ludności zamieszkałej na Ukrainie. Przykład Kijowa jest odosobniony, przynajmniej co do skali przedsięwzięcia. Czasem do transportów wojskowych doczepiano 1-2 wagony dla uchodźców. Z reguły jednak ewakuacja cywilna odbywała się pociągami lokalnymi, tak jak w opisanej przez Lisa-Błońskiego Winnicy, które dowoziły uchodźców do najdalej na zachód położonej stacji na linii, jaką obsługiwały. Tam pasażerowie musieli sami zatroszczyć się o dalszy transport na zachód. Nie było to łatwe, ponieważ pociągi kursowały rzadko, a większość taboru kolejowego wojsko zabrało na własne potrzeby. Tysiące uchodźców ruszały w drogę pieszo lub wozami konnymi, na które ładowano dobytek. Ślady takiej ewakuacji napotykamy w literaturze pamiętnikarskiej - między innymi u cytowanego wyżej Lisa-Błońskiego - nie doczekała się ona jeszcze opisu historyka.

Mimo wielu trudności i lokalnych niepowodzeń zdołano utrzymać ciągłość ruchu transportów ewakuacyjnych; zawdzięczano to między innymi pracy wojsk kolejowych. Wartość uratowanego majątku wojskowego nie jest znana i wątpliwe jest to, aby udało się ją ustalić na podstawie aktualnie dostępnej bazy źródłowej. Słuszne wydaje się twierdzenie, że ocalono większość zapasów i zdolnego do ruchu taboru kolejowego. Podczas odwrotu zdołano dokonać na opuszczanych liniach i węzłach komunikacyjnych rozległych zniszczeń, które poważnie utrudniły nieprzyjacielowi uruchomienie transportu kolejowego na opuszczanych przez Polaków terenach.

Trudno ocenić jest rolę, jaką w ewakuacji odegrały tabory wojskowe, w ogromnej większości o ciągu konnym. Kwestia dotyczy zarówno odwrotu na Ukrainie, jak i opisanego niżej odwrotu na ziemiach litewsko-białoruskich. Cofającym się armiom towarzyszył ogromny, aczkolwiek mało pojemny tabor konny, tarasujący drogi, spowalniający marsz wojska i wymagający osłony, jako że w przypadku napotkania większych oddziałów nieprzyjaciela łatwo padał ich łupem. Z uwagi na nieregularność dostaw zaopatrzenia $\mathrm{z}$ kraju i powszechnie odczuwane braki tabory traktowano jako swoistą składnicę sprzętu, zdobytej i niezgłoszonej dowództwom broni, nadliczbowej nieujawnianej w meldunkach rezerwy amunicji itp. Było to zjawisko nagminne i oficjalnie tępione przez dowództwa, ale w rzeczywistości tolerowane w dobrze 
pojętym interesie oddziałów, które w ten sposób starały się zapewnić sobie "nieewidencjonowane" zapasy, pozwalające kontynuować walkę nawet kiedy dostawy z kraju zostaną chwilowo przerwane. Do przewożenia tych nieewidencjonowanych zapasów służyły częstokroć także wagony kolejowe bezprawnie przetrzymywane przez dywizje i brygady ${ }^{36}$.

Intencją dowództw było ograniczenie liczby taborów, zwłaszcza że brakowało koni dla jazdy i artylerii. Nie przynosiło to jednak większych rezultatów. Liczba wozów taborowych malała w stopniu nieadekwatnym do oczekiwań, by ponownie szybko wzrastać po zwycięstwie nad Wisłą. Podczas odwrotu tabory towarzyszące oddziałom wojska zabierały z magazynów głównie produkty żywnościowe, amunicję, umundurowanie, bieliznę. Jako że garnizony i ośrodki zapasowe walczących oddziałów dysponowały własnymi, z reguły szczupłymi taborami, toteż ewakuowano je w większości koleją; transport konny miał w tej ewakuacji niewielki udział. Podobnie wyglądała ewakuacja urzędów i władz cywilnych. Pogłowie koni na ziemiach polskich zostało wyniszczone przez Wielką Wojnę i rabunkową politykę okupantów do tego stopnia, że trzeba było importować konie dla kawalerii i artylerii; powszechnie brakowało zwierząt pociągowych w miastach i w rolnictwie ${ }^{37}$. Reasumując, wydaje się, że w zestawieniu z około 20 tys. wagonów kolejowych użytych do wywiezienia rozmaitych zapasów z ziem wschodnich, wojskowy tabor konny odegrał w tej ewakuacji raczej rolę pomocniczą ${ }^{38}$.

Dodajmy w tym miejscu, że szczupły wojskowy tabor samochodowy wykorzystywano w pierwszej kolejności do dowozu zaopatrzenia walczącym oddziałom na linię frontu; wypełniając to zadanie, wojska samochodowe odegrały większą rolę w wojnie z Rosją bolszewicką, niż jesteśmy im skłonni przypisywać ${ }^{39}$.

${ }^{36}$ Literatura na ten temat jest bardzo skromna. Z okresu międzywojennego należy wymienić przede wszystkim cenne wspomnienia Stanisława Burnagela (idem, Wspomnienia wojenne intendenta dywizji, Warszawa 1934) i opracowanie Stanisława Deca: idem, Intendentura 7-ej dywizji piechoty $w$ wojnie o wywalczenie granic Polski. Szkic historyczno-taktyczny z zakresu operacyjnej służby sztabów, Warszawa 1934 oraz artykuł o odwrocie taborów 3 Armii z Kijowa opublikowany w tymże roku na łamach „Przeglądu Piechoty”.

${ }^{37}$ Podczas ofensywy na Kijów wiosną 1920 r. oddziały polskie musiały pozostawić na tyłach niemal całą artylerię ciężką z uwagi na brak koni pociągowych typu "A" (koni artyleryjskich zdolnych do ciągnięcia armat i wozów z amunicją artyleryjską). W rozkazie NDWP nr 3575/1 z 1 IV 1920 r. czytamy: „Obecny stan artylerii na froncie charakteryzuje się ogólnym brakiem koni i ludzi a nie brakiem dział i amunicji, a szczególnie dotkliwy brak koni w jej oddziałach oraz brak kolumn taborowych do przewozu dodatkowej amunicji [...]"; CAW-WBH, Dowództwo 7 Armii, sygn. I.311.7.75, Uruchomienie artylerii frontowej, Dowództwo 7 Armii, m.p. 12 IV 1920 r., b.p.

${ }^{38}$ Szerzej na temat taboru kolejowego użytego do ewakuacji zapasów zob. J. Odziemkowski, Polskie kolejnictwo wojskowe..., s. 69-72.

${ }^{39}$ Więcej na ten temat zob. J. Odziemkowski, Wojska samochodowe - niedoceniany czynnik polskiego zwycięstwa w 1920 roku [w:] Bitwa Warszawska 1920 roku w obronie niepodległości, 
4 lipca 1920 r. wojska Frontu Zachodniego Michaiła Tuchaczewskiego, uzupełnione i wzmocnione szeregiem dywizji ściągniętych z głębi Rosji, rozpoczęły drugą ofensywę. Po przegranej bitwie nad Autą (4-5 lipca) polska 1 Armia rozpoczęła odwrót, a w ślad za nią do odwrotu przystąpił cały Front Północno-Wschodni.

5 lipca 1920 r. NDWP rozesłało do dowództw frontów, armii, wszystkich DOE i oddziałów Sztabu Generalnego, do MSWojsk., a także pozostałych ministerstw „Instrukcję Ewakuacyjną”, przygotowaną na podstawie dotychczasowych doświadczeń. W uzasadnieniu wydania instrukcji czytamy: „Ze względu na obecną sytuację na froncie wschodnim zachodzi potrzeba przygotowania i stopniowego przeprowadzenia ewakuacji pewnych obszarów Ziem Wschodnich, Wołynia i Frontu Podolskiego oraz pewnej części Wschodniej Małopolski. Naczelne Dowództwo przez zarządzenie to pragnie przede wszystkim zapobiec panice i nieładowi szerzonemu już teraz przez wrogie nam elementy oraz nierozumnych przedwczesnych uciekinierów, jakkolwiek stan naszych operacji na froncie pozwala dotychczas spodziewać się, że ziemie te nie zostaną oddane nieprzyjacielowi. Ponieważ wchodzą tu w rachubę nie tylko ziemie należące do obszaru wojennego, administrowanego przez Naczelne Dowództwo, ale także ziemie należące wojskowo do MSWojsk., zarządzenie to wydaje Nacz. Dow. w porozumieniu z MSWojsk"40.

Instrukcja dzieliła obszar który należało przygotować do ewakuacji na dwie strefy. Zachodnią granicę strefy I wyznaczały: rz. Seret-Brody-rz. Styr-Pińsk i linia kol. Baranowicze-Lida-Wilno-rz. Wilja, zaś zachodnią granicę strefy II: rz. Złota Lipa-Krasne-rz. Bug-linia kol. Brześć Litewski-Czeremcha-Białystok. Nakazano przystąpienie do stopniowej ewakuacji strefy I, natomiast strefa II mogła być ewakuowana tylko na wyraźny rozkaz NDWP.

Dowództwa frontów i armii otrzymały rozkaz, aby w swoich pasach działania podzieliły obszar strefy I na dwa pasy - A i B. Pas A oznaczał teren przyległy do frontu, na którym natychmiast przystępowano do ewakuacji przymusowej, zaś na obszarze pasa B należało przygotować się do ewakuacji planowej $^{41}$.

Instrukcja nakazywała wywiezienie całego majątku wojskowego (w tym zdobycznego), z wyjątkiem tej części, która była potrzebna do prowadzenia walki. Z majątku cywilnego w pierwszej kolejności podlegał ewakuacji majątek państwowy (zwłaszcza akta sądowe, metryki, księgi hipoteczne, środki pieniężne i aktywa złożone w bankach itp., w drugiej rodziny urzędników

red. J. Odziemkowski, Warszawa 2006, s. 165-180.

${ }^{40}$ CAW-WBH, Dowództwo Frontu Północno-Wschodniego, sygn. I.310.11.20, /NDWP SGen./Nr 34000/IV. Instrukcja ewakuacyjna z dn. 5 VII 1920 r., b.m., b.p.

${ }^{41}$ Dla majątku cywilnego ewakuacja planowa miała tę zaletę, że właściciel ewakuowanych dóbr sam mógł wybrać trasę dojazdu i stację docelową, ale tylko na obszarach przydzielonych dla ewakuacji cywilnej przez wojsko. 
i wojskowych, zabytki sztuki, ludność cywilna (bez dobytku domowego), „[...] personel zaś władz i urzędów pod sądowo-karną odpowiedzialnością na samym końcu"42.

Podstawowym środkiem ewakuacji pozostała kolej. W przypadku ewakuacji przymusowej miejsca załadunku linię kolejową, którą miały jechać transporty, i miejsce ich przeznaczenia wyznaczało dowództwo frontu; spodziewano się w ten sposób zapobiec zatorom na kolejach. Naczelne Dowództwo wskazywało centra ewakuacji dla wysyłanego do kraju majątku wojskowego objętego ewakuacją przymusową ${ }^{43}$ :

- dla 6 Armii, części 2 Armii i Okręgu Generalnego Lwów były to Rzeszów, Tarnów i Nowy Sącz;

- dla 3 Armii i części 2 Armii - Radom i Kielce;

- dla 1, 4 i 7 Armii oraz Okręgu Generalnego Grodno - Łowicz, Łódź, Kutno.

Natomiast przymusowo ewakuowany majątek cywilny należało kierować:

- z Małopolski Wschodniej (Galicji Wschodniej) do Krakowa, Oświęcimia, Suchej;

- z Wołynia i Frontu Podolskiego do Piotrkowa, Nowo-Radomska (Radomska), Kielc;

- majątek Centralnego Zarządu Ziem Wschodnich do Torunia i Włocławka. Ludność mogła być ewakuowana tylko z obszaru podlegającego ewakuacji przymusowej i dowożona była na teren ogólnie pokrywający się wyznaczonymi w głębi kraju centrami ewakuacji majątku cywilnego; na tej zasadzie np. mieszkańcy terenów znajdujących się pod Centralnym Zarządem Ziem Wschodnich odwożeni byli na Pomorze i do Wielkopolski, gdzie znajdowały się centra ewakuacji majątku cywilnego z obszarów podlegających Centralnemu Zarządowi Ziem Wschodnich. Ewakuowanie mieszkańców z obszarów nieobjętych przymusową ewakuacją następowało jedynie na polecenie władz wojskowych.

Kierowanie ewakuacją „Instrukcja” przekazała władzom wojskowym: na obszarze wojennym dowództwom armii, na obszarze kraju DOGen. Dowódcy frontów i armii wyznaczali specjalnych oficerów ewakuacyjnych. Oficerowie powoływali Komisje Ewakuacyjne (Komisje EWA) z osób delegowanych przez zainteresowane władze cywilne; osoby te miały status doradców oficera ewakuacyjnego. Dowódcy OGen. kierowali ewakuacją przez referaty ewakuacyjne (EWA). Komisje i referaty EWA na podstawie rozesłanej „Instrukcji” opracowywały szczegółowe plany ewakuacji zarówno

\footnotetext{
${ }^{42}$ Ibidem.

${ }^{43} \mathrm{~W}$ kolejnych rozkazach i instrukcjach centra ewakuacji dla wojska nazywane były wojskowymi rejonami koncentracyjnymi, a dla ludności i majątku cywilnego cywilnymi rejonami koncentracji. Centra ewakuacji nie uległy zmianie do zakończenia Bitwy nad Wisłą.
} 
majątku wojskowego, jak i cywilnego, wyznaczały jej kolejność, nadzorowały przebieg. Powodzenie ewakuacji w dużej mierze zależało od współpracy czynników wojskowych i cywilnych, wśród tych ostatnich przede wszystkim od Ministerstwa Kolei Żelaznych. Zarządzenie NDWP z 28 lipca 1920 r. przypominało, że władze cywilne we własnym interesie powinny utrzymywać ścisłą łączność z dowództwami wojskowymi odpowiadającymi za ewakuację i stosować się ściśle do ich wskazówek ${ }^{44}$.

Reasumując, „Instrukcja” z 5 lipca wprowadzała uregulowania, których celem było zapobieżenie chaosowi ewakuacyjnemu. Jasno określała kolejność ewakuacji i miejsca rozlokowania ewakuowanego majątku. Wprowadzała mechanizmy, mające zapobiegać powstawaniu zatorów kolejowych, grożących dezorganizacją dowozu zaopatrzenia na front i ruchu transportów operacyjnych. Między innymi z tego powodu całą ewakuację cywilną skierowano od razu na obszary położone na zachód od Sanu i Wisły.

W pierwszych dniach odwrotu z Polesia i Białorusi na tyłach Grupy Poleskiej gen. Sikorskiego nieoczekiwanie pojawiły się transporty ewakuacyjne grupy płk. Józefa Rybaka. Mogło to spowodować zablokowanie linii kolejowych i załamanie harmonogramu ewakuacji Grupy Poleskiej. W porę udało się zaradzić temu niebezpieczeństwu, przekierowując i przyspieszając ruch transportów Grupy płk. Rybaka. Aby uchronić się przed powtórką takiej sytuacji, 7 lipca MSWojsk. wydało „Ogólną Instrukcję Ewakuacyjną”, która wprowadzała dodatkowo szereg uregulowań szczegółowych: wojskowe rejony koncentracyjne dzieliła na sektory przydzielane poszczególnym armiom i OGen., uściślała zakres obowiązków i kompetencji dowództw rejonów i sektorów, kompetencje i czynności DOGen. w przygotowaniu ewakuacji podległego im obszaru, zakres pracy referatów ewakuacyjnych powoływanych przez DOGen. Wyznaczyła linie kolejowe, którymi ewakuacja miała być prowadzona ${ }^{45}$ :

- dla obszaru podległego 6 Armii i OGen. Lwów linie: Podwołoczyska-Tarnopol-Lwów-Rzeszów-Tarnów oraz Husiatyn-Buczacz-Stanisławów-Stryj-Sambor-Sanok-Jasło-Stróże-Tarnów;

- dla obszaru 2 Armii linię Łuck-Włodzimierz Wołyński-Sokal-Rawa Ruska-Jarosław-Rzeszów-Nowy Sącz;

- dla obszaru 3 Armii linię Sarny-Kowel-Lublin-Dęblin-Radom-Kielce;

- dla OGen. Lublin linię Lublin-Dęblin-Radom;

- dla obszaru 1 Armii linię Mołodeczno-Lida-Wołkowysk-Białystok-Warszawa;

${ }^{44}$ CAW-WBH, Dowództwo Frontu Południowo-Wschodniego, sygn. I.310.7.29, /NDWP, Oddział IV/ 28 VII 1920 r. Ewakuacja: strefa III i IV, b.m., b.p.

${ }^{45}$ CAW-WBH, Dowództwo Frontu Północno-Wschodniego, sygn. I.310.11.20, /MSWojsk. Sztab Oddz. I, Sekcja Organizacyjna/ Nr 6953/Org., Ogólna instrukcja ewakuacyjna, Warszawa 7 VII 1920 r., b.p. 
- dla obszaru 4 Armii linie: Pińsk-Brześć Litewski-Warszawa-Skierniewice-Koluszki-Łódź oraz Mińsk-Baranowicze-Słonim-Wołkowysk-Siedlce-Warszawa-Skierniewice-Łódź;

- dla 7 Armii linię Wilno-Grodno-Białystok-Warszawa-Sochaczew-Łowicz;

- dla OGen. Grodno linię Grodno-Białystok-Warszawa-Sochaczew-Łowicz. „Instrukcja” wprowadziła następujące zasady: 1. urzędy cywilne na ewakuowanym terenie wykonują swoje czynności możliwie jak najdłużej; 2. cywilne transporty ewakuacyjne są przeplatane wojskowymi; 3. ostatni transport cywilny odjeżdża przed ostatnim transportem wojskowym.

Punkt C zamieszczony w części VII „Ogólnej instrukcji” stanowił, że wojsko będzie dostarczać wagony dla ewakuacji cywilnej „w miarę możności”. To zastrzeżenie wyraźnie wskazywało na priorytety obowiązujące podczas prowadzenia ewakuacji.

W ciągu kolejnych trzech tygodni czyniono wysiłki, aby ewakuować z ziem litewsko-białoruskich jak najwięcej sprzętu, zapasów taboru kolejowego normalno- i szerokotorowego. Główne nurty ewakuacji szły liniami: Wilno-Grodno-Białystok-Warszawa, Mołodeczno-Lida-Wołkowysk-Białystok-Warszawa, Baranowicze-Brześć Litewski. Najwięcej taboru pochłonęła ewakuacja personelu wojskowego, zakładów i zapasów znajdujących się w Wilnie. Kwatermistrz 7 Armii zgłosił zapotrzebowanie na 700 wagonów towarowych krytych, 120 lor, 14 cystern i 15 wagonów osobowych ${ }^{46}$.

W przeciwieństwie do terenów ukraińskich, ewakuacja na ziemiach litewsko-białoruskich odbywała się pod stałym, silnym naporem nieprzyjaciela, w warunkach nieustającego odwrotu wojsk, które przeważnie cofały się w tempie od kilkunastu do ponad dwudziestu kilometrów na dobę. Były to okoliczności sprzyjające panikarskim nastrojom wśród formacji tyłowych, a także wybuchom paniki wśród ludności cywilnej nie spodziewającej się tak szybkiego marszu Armii Czerwonej. Obraz chaotycznej, nagłej ewakuacji znajdujemy m.in. w zapiskach Andrzeja Rostworowskiego, oficera 14 DP, który tak zapamiętał krótki pobyt w Mińsku Litewskim:

„Do Mińska dojechaliśmy nad ranem. Nad miastem snuły się dymy, w paru miejscach widać było pożary. Ponieważ musieliśmy brać wodę i drzewo czy węgiel, wziąłem rower i skoczyłem do miasta. Smutny to był widok. Puste ulice, gdzieniegdzie pożary, dość odległa strzelanina i kanonada [...]. Wracam na dworzec, teraz dopiero widzę tłumy szukających okazji do wyjazdu, bodaj uczepienia się jakiegoś wagonu. Na rampie sterty pozostawionych waliz i kufrów. Długo szukam naszego pociągu, który dość znacznie posunął się

\footnotetext{
${ }^{46}$ CAW-WBH, Dowództwo 7 Armii, sygn. I.311.7.78, Sprawozdanie z konferencji odbytej u kwatermistrza 7 Armii w dniu 5 VII 1920 r., b.m., b.p.
} 
w kierunku na zachód. W dwu dużych budynkach między torami, mieszczących magazyny, jakiś intendent rozdaje ludności workami cukier i mąkę" ${ }^{37}$.

Nierzadko ignorowano zarządzenia władz kolejowych, samowolnie zajmowano wagony i parowozy. 20 lipca NDWP delegowało oficerów sztabowych do Białegostoku, Brześcia Litewskiego, Dęblina, Modlina, Siedlec, a także do Lwowa i Stanisławowa, bowiem podobne wypadki odnotowano również w Galicji Wschodniej, z zadaniem usprawnienia przepływu transportów. Najtrudniejsza sytuacja powstała w Białymstoku, gdzie 22 lipca na stacji znajdowało się 4950 wagonów, a każdego dnia przybywało ok. 1,2 tys. nowych. Sytuację opanowano dzięki wysiłkom kolejarzy i delegowanego przez NDWP ppłk. Jana Klima, który wymuszał na dowództwach transportów, powagą swej delegacji, podporządkowanie się poleceniom władz kolejowych.

Kiedy na węźle białostockim starano się uratować przybyłe ze wschodu transporty ewakuacyjne na prawym, południowym skrzydle frontu, po załamaniu się obrony polskiej na linii Zbrucza i niepowodzeniach na Wołyniu, 25 lipca dowództwo Frontu Południowo-Wschodniego wydało zarządzenie o przesunięciu na zachód granicy obszaru wojennego. Nakazano ewakuację zagrożonych przez nieprzyjaciela powiatów włodawskiego, chełmskiego, hrubieszowskiego, tomaszowskiego i części powiatu włodzimierskiego, które były przekazywane Okręgom Etapowym 2 i 3 Armii. Na odcinku 6 Armii za obszar wojenny uznano teren na wschód od Sanu. Władze cywilne miały pozostać na miejscu, natomiast zbędne do ich funkcjonowania urządzenia, materiały, zapasy należało skierować do cywilnego rejonu koncentracyjnego Piotrków-Nowo-Radomsk (Radomsko)-Częstochowa. W powiatach przekazanych Armii należało nadal kontynuować ewakuację zgodnie z zasadami zawartymi w instrukcji z 5 lipca ${ }^{48}$.

Ze względu na położenie na froncie 28 lipca NDWP wyznaczyło jako III strefę ewakuacyjną obszar „[...] od Brześcia wzdłuż Bugu a dalej na północny wschód i wschód od zwróconych w stronę kraju granic powiatów Sokołów, Węgrów, Ostrów i Ostrołęka" " Zarządzono natychmiastową przymusową ewakuację tego terenu i niezwłoczne dokończenie przymusowej ewakuacji skrawków stref I i II, znajdujących się jeszcze w rękach wojsk polskich. Transporty, zależnie od ładunku, należało kierować do centrum

\footnotetext{
${ }^{47}$ A. Rostworowski, Ziemia, której już nie zobaczysz, Warszawa 2001, s. 344-345.

${ }^{48}$ CAW-WBH, Dowództwo Frontu Południowo-Wschodniego, sygn. I.310.7.26, Obszar wojenny, przesunięcie granicy na zachód, b.m. 25 VII 1920 r., b.p.; J. Odziemkowski, Polskie formacje etapowe w Galicji Wschodniej..., s. 156.

${ }^{49}$ CAW-WBH, Dowództwo Frontu Południowo-Wschodniego, sygn. I.310.7.29, Naczelne Dowództwo WP 28 VII 1920 r., Ewakuacja: strefa III i IV, b.m., b.p.
} 
ewakuacyjnego dla majątku wojskowego Łowicz-Łódź-Kutno i dalej wzdłuż linii kolejowej Łódź-Kalisz, lub do centrów ewakuacyjnych dla majątku cywilnego Toruń-Włocławek i Bydgoszcz-Inowrocław. Natomiast transporty ewakuacyjne z Galicji Wschodniej szły do centrów ewakuacyjnych w rejonie Rzeszów-Tarnów-Nowy Sącz.

W tym samym zarządzeniu jako IV strefę wyznaczono obszar na wschód od linii kolejowej Ławoczne-Stryj-Chodorów-Lwów-Rawa Ruska, stąd od zachodnich granic powiatów Tomaszów, Hrubieszów, Chełm, Włodawa, Radzyń i dalej na wschód od linii kolejowej Łuków-Siedlce-Mińsk Mazowiecki-Tłuszcz-Wyszków i dalej na wschód i północ od rzek Narwii i Wkry. Z IV strefy należało ewakuować archiwa państwowe i zbędne sumy z kas państwowych. Zakazano natomiast ewakuacji ludności, władz i urzędów i zabroniono „bezwzględnie” jakichkolwiek przygotowań do ewakuacji we Lwowie i Warszawie, aby nie powodować paniki.

2 sierpnia dowództwo Frontu Południowo-Wschodniego zarządziło natychmiastową przymusową ewakuację wojskową i cywilną pasa przyfrontowego rozciągającego się wzdłuż zachodniego brzegu Bugu od Kodenia do Uściługu i sięgającego $30 \mathrm{~km} \mathrm{w}$ głąb kraju. Jej przeprowadzenie powierzono DOE 2 i 3 Armii w porozumieniu ze starostwem w Chełmie.

6 sierpnia, w związku z decyzją opuszczenia przez wojska linii Bugu, cały teren na wschód od Wisły uznano za obszar wojenny, uruchomiono także ewakuację IV strefy ${ }^{50}$.

W sierpniu 1920 r. wojna, a wraz z nią ewakuacja, wkroczyły na obszary podległe dyrekcjom kolejowym warszawskiej, radomskiej, lwowskiej, stanisławowskiej, krakowskiej i gdańskiej. Zagrożonych zostało szereg ośrodków zapasowych pułków piechoty, jazdy i artylerii, które należało ewakuować w pierwszej kolejności wraz z wyposażeniem, zapasami broni i amunicji, bowiem od ich funkcjonowania zależało uzupełnianie strat oddziałów frontowych. Koleją ewakuowano około 30 tys. rannych i chorych żołnierzy wraz z personelem szpitalnym z terenów zagrożonych przez nieprzyjaciela. Starano się również ewakuować jak największą liczbę kolejarzy, poza tymi, którzy byli niezbędni do utrzymania do ostatniej chwili ruchu kolejowego. W Galicji podstawiano specjalne pociągi ewakuacyjne dla kolejarzy i ich rodzin.

Według autora zarysu historii 2 Pułku Wojsk Kolejowych IV Batalion Kolejowy ewakuował i niszczył linie Białystok-Ostrołęka, Łomża-Śniadowo, Pilawa-Falenica tak dokładnie, że „[...] ani jednego wozu kolejowego, ani jednej rodziny cywilnych pracowników kolejowych nie pozostawiono na pastwę wroga, wszystkie magazyny i warsztaty kolejowe opróżniono, a drogi zawalono przeszkodami w postaci zniszczonych mostów, zerwanych torów,

${ }^{50}$ CAW-WBH, Dowództwo Frontu Południowo-Wschodniego Oddział IV, sygn. I.310.7.29, 2 VIII 1920 r., Ewakuacja Chełma, b.m., b.p.; 6 VIII 1920 r., Likwidacja Dowództw Okręgów Etapowych 2 i 3 Armii, b.m., b.p. 
wysadzanych obiektów stacyjnych [...]"51. Żołnierze wojsk kolejowych, którym powierzano takie zadania, wycofywali się przeważnie $\mathrm{z}$ ostatnimi oddziałami polskimi, niejednokrotnie już pod ogniem nieprzyjaciela. Rozmiary uszkodzeń dokonanych przez Polaków w trakcie ewakuacji były tak znaczące, że uniemożliwiły bolszewikom szybką naprawę linii kolejowych na zachód od Bugu i Niemna. W dobie bitwy nad Wisłą transport kolejowy dla wojsk Tuchaczewskiego dochodził tylko do tych rzek; dalej zaopatrzenie musiało być dostarczane na front taborem konnym. Pogłębiało to kłopoty logistyczne Armii Czerwonej oddalonej od swych centrów zaopatrzenia i ograniczało jej możliwości działania; np. podczas walk o Warszawę trzeba było zmniejszyć dzienną dotację amunicji dla artylerii wspierającej uderzenie na stolicę Polski.

Warto zaznaczyć, że w dniach odwrotu znad Bugu pododdziały wojsk kolejowych często dokonywały uszkodzeń poprzez wymontowanie i zabranie urządzeń ważnych dla funkcjonowania stacji. Robiono to celowo, aby podczas kontrofensywy można było bez zbędnej zwłoki na powrót uruchomić linie kolejowe i wysyłać transporty z zaopatrzeniem i uzupełnieniami w ślad za frontem. Pomysł ten dobrze sprawdził się w praktyce podczas pościgu za Armią Czerwoną uchodzącą znad środkowej Wisły. Dlatego strona polska potrafiła zaskakująco sprawnie uruchamiać połączenia kolejowe, transporty wojsk, a także transporty z zaopatrzeniem, które szły w ślad za nacierającymi oddziałami ${ }^{52}$.

Ewakuacja objęła wszystkie linie kolejowe prowadzące ze wschodu nad środkową Wisłę. Do 14 sierpnia 1920 r. ewakuowano stacje od Mławy do Nasielska, od Łap i Ostrołęki do Wołomina, od Brześcia nad Bugiem do Rembertowa i od Dęblina do Wawra. Wywieziono personel, cały sprzęt i urządzenia, tak aby nieprzyjaciel nie mógł od razu przystąpić do naprawy kolei i nie miał kim jej obsługiwać. Tylko w Rembertowie i Wawrze pozostawiono aparaty telefoniczne i telegraficzne do dyspozycji kompanii kolejowych. Kolejarze pełnili służbę do ostatniej chwili, dopóki wojsko trzymało stacje w posiadaniu. Niektórzy z własnej inicjatywy pozostawali na miejscu, kiedy stacje stawały się obiektem ataku nieprzyjaciela, aby przy pomocy urządzeń kolei dopomóc w utrzymywaniu łączności między oddziałami i grupami wojsk polskich. Kilku kolejarzy zostało odznaczonych za swoją postawę Krzyżami Walecznych ${ }^{53}$.

${ }^{51}$ J. Wyporek, Zarys historii wojennej 2-go..., s. 19.

${ }^{52}$ Przykładowo już 18 sierpnia można było rozpocząć załadowanie na pociągi oddziałów 1 Dywizji Litewsko-Białoruskiej broniącej Warszawy i wysłać je przez Siedlce do Platerowa, gdzie transporty dotarły 19 sierpnia; zob. J. Odziemkowski, Żotnierze z kresów pótnocno-wschodnich w obronie Warszawy, sierpień 1920, Brzeście 2014, s. 140.

\footnotetext{
${ }^{53}$ Sprawozdanie z działalności Dyrekcji Kolei Państwowych w Warszawie 1918-1928,
} Warszawa 1928, s. 18. 
Transporty ewakuacyjne kierowane na tereny położone na zachód od Wisły mogły korzystać z mostów żelaznych w Modlinie, Warszawie, Dęblinie i Sandomierzu (adaptowanych do ruchu kołowego), mostów kołowych w Warszawie i Dęblinie, mostów drewnianych w Puławach i Annopolu i ciężkiego mostu pontonowego w Modlinie. W trakcie budowy były most pontonowy w Warszawie i most na berlinkach w Górze Kalwarii. Ponadto przygotowywano do uruchomienia promy parowe w Jabłonnie i Górze Kalwarii.

W gorączce ewakuacji, pod nieustannym naporem nieprzyjaciela, pojawiał się również chaos. Popełniano błędy, które nie ominęły także jednostek wojskowych. 4 DP szykująca się do obrony linii Wisły utraciła swój urząd gospodarczy i piekarnię, które zostały porwane nurtem ewakuacji podczas odwrotu za Wisłę. Piekarnia odjechała z transportami ewakuacyjnymi do Skierniewic i kwatermistrz dywizji odszukał ją po paru dniach, a urząd gospodarczy zawędrował aż do Lublina i dołączył do macierzystej jednostki dopiero 22 sierpnia $^{54}$. Również $14 \mathrm{DP}$, zdążająca do miejsca koncentracji nad Wieprzem, na kilka dni straciła kontakt ze swoim urzędem gospodarczym, który odjechał do Jędrzejowa.

W Galicji, gdzie postępy nieprzyjaciela były znacznie powolniejsze, ewakuacja mogła przebiegać bez gwałtownego pośpiechu. Kiedy nadchodził rozkaz dalszego odwrotu, dowództwo frontu ogłaszało odejście armii na nowe pozycje oraz odpowiednie przesunięcie na zachód obszaru operacyjnego i etapowego. W ślad za tym kolejne powiaty obejmowane były przymusową ewakuacją, a leżące na zachód od nich przygotowaniami do ewakuacji. Największym zagrożeniem dla planowego wycofania ludzi i zasobów okazały się działania kawalerii nieprzyjaciela. Wrażenie sukcesów Armii Konnej Budionnego było tak wielkie, że pojawienie się nawet niewielkich oddziałów jazdy bolszewickiej na tyłach frontu potrafiło wzniecić panikę zupełnie nieadekwatną do rozmiarów niebezpieczeństwa. Kiedy zagon 8 DK Czerwonego Kozactwa opanował Stryj, w całym drohobyckim zagłębiu naftowym wybuchł popłoch. Z Drohobycza uciekły władze cywilne razem z komisarzem rządu i burmistrzem. Rozpoczęła się nieskoordynowana, paniczna ewakuacja sąsiednich miejscowości. Aby ją opanować, dowódca obrony zagłębia naftowego ppłk Józef Sopotnicki musiał „wprowadzić dyktaturę wojskową”. Na szczęście przeciwnik nie realizował celów operacyjnych, nastawiając się głównie na sianie zamętu na polskich tyłach i rabunek. Po obrabowaniu Stryja czerwona jazda opuściła miasto, które Polacy ponownie obsadzili. Panika przejściowo ogarnęła także garnizon Stanisławowa, który pod wpływem plotek o porażkach

${ }^{54}$ S. Burnagel, Ze wspomnień wojennych intendenta dywizji, „Przegląd Intendencki” 1931, z. 3 (lipiec-wrzesień), s. 14-16. 
na froncie bez rozkazu opuścił miasto, został jednak w porę zawrócony przez kpt. Romualda Kwiatkowskiego, dowódcę rejonu obronnego Stanisławów ${ }^{55}$.

Wydaje się, że główną przyczyną wybuchów paniki była - podobnie jak trzy miesiące wcześniej na Białorusi - szwankująca łączność i brak rzetelnych informacji o położeniu na froncie.

Masowa ewakuacja w niespotykanej dotąd skali, prowadzona równocześnie na całej szerokości frontu, była wielkim obciążeniem dla kolejnictwa polskiego. Po załadunku wagony jechały przez kilka dni, a niekiedy znacznie dłużej, w składzie pociągów, które wolno sunęły zatłoczonymi szlakami kolejowymi do centrum kraju, raz po raz zjeżdżając na bocznice, aby przepuścić transporty operacyjne. Kiedy już dotarły na miejsce przeznaczenia, czekały w kolejce na rozładunek. Przydzielając wagon do ewakuacji, władze kolejowe musiały liczyć się z tym, że przez dłuższy czas nie będzie można wykorzystać go do innych celów. Skala ewakuacji i fragmentaryczne dane liczbowe (850 wagonów niezbędnych do ewakuacji zapasów z Wilna, 210 wagonów potrzebnych do ewakuowania zapasów aprowizacyjnych $\mathrm{z}$ terenów na wschód od Mińska, ponad 11 tys. wagonów, jakie przeszły przez węzeł białostocki w ciągu kilku dni lipca) pozwalają przypuszczać, że ewakuacja angażowała stale co najmniej kilkanaście tysięcy z ok. 70 tys. wagonów, jakimi dysponowało wówczas (łącznie z ewakuowanym ze wschodu taborem szerokotorowym) polskie kolejnictwo. Tak wielkie, wymuszone koniecznością, uszczuplenie taboru musiało odbić się ujemnie na możliwościach transportowych kolei.

Z punktu widzenia wydolności transportu kolejowego należy dostrzegać również pozytywy odwrotu. Cofający się front wszedł na obszary o gęstszej sieci dróg i linii kolejowych, a odległości dzielące centra zaopatrzenia od walczących wojsk uległy znacznemu skróceniu. Problemem było zaangażowanie w koniecznej przecież ewakuacji dużej liczby wagonów. Od pierwszych dni sierpnia podejmowano usilne działania, aby transporty ewakuacyjne jak najszybciej rozładować i odzyskać cenny tabor niezbędny dla transportu mas wojsk i zaopatrzenia w ramach przygotowań do bitwy nad Wisłą z wojskami Tuchaczewskiego. Nakazano ścisłą współpracę w tej sprawie szefów kolejnictwa frontów i armii z komisjami ewakuacyjnymi w centrach ewakuacyjnych;

\footnotetext{
${ }^{55}$ CAW-WBH, Dowództwo Frontu Południowego, sygn. I.311.9.12, /Dowództwo wojska Zagłębia Naftowego/ meldunek dla dowództwa Frontu Południowego, b.m. 24 VIII 1920 r., b.p.; sygn. I.311.9.17, Meldunek dowództwa rejonu obronnego Stanisławów do DOGen. Lwów z 25 VIII 1920 r, b.m., b.p.; szerzej na temat wypadków w Stryju i Stanisławowie zob. J. Odziemkowski, Obrona Drohobycko-Borysławskiego Zagłębia Naftowego przez wojska polskie i ukraińskie w sierpniu 1920 roku, „Studia i Materiały Centralnej Biblioteki Wojskowej im. Marszałka Józefa Piłsudskiego" 2014, nr 1, s. 87-101.
} 
gdyby brakowało personelu cywilnego do rozładunku, dopuszczano możliwość użycia do tej pracy kompanii wojsk kolejowych ${ }^{56}$.

Dużym sukcesem było ewakuowanie ze wschodu funkcjonującego tam taboru kolejowego. Według danych NDWP straty kolejnictwa polskiego na całym froncie w okresie od 1 stycznia 1920 r. do zawieszenia broni objęły 30 parowozów i 1350 wagonów normalnotorowych oraz 70 parowozów i 2161 wagonów szerokotorowych ${ }^{57}$. Część z nich poniesiono podczas pierwszej ofensywy Tuchaczewskiego. Trudna do określenia liczba wagonów i parowozów normalnotorowych została pozostawiona $\mathrm{z}$ uwagi na fatalny stan techniczny sprzętu - wspominają o tym relacje żołnierzy i kolejarzy, niestety, bez podania liczb ${ }^{58}$. Wydaje się, że straty podczas odwrotu można szacować na około tysiąc sprawnych wagonów normalnotorowych i ponad dwadzieścia parowozów. W okresie od początku ostatniej dekady lipca do bitwy nad Wisłą ze wschodu przybyło do kraju ponad 20 tys. wagonów. Straty sięgały zatem prawdopodobnie około $5 \%$ taboru, lub też niespełna $7 \%$, gdyby wszystkie utracone przez koleje polskie wagony zaliczyć na karb ewakuacji. Jak na warunki i tempo odwrotu można je uznać za minimalne.

Z Ukrainy ewakuowano do Lwowa 20 szerokotorowych parowozów, 175 wagonów osobowych i ok. 1500 towarowych. Część taboru ukraińskiego dojechała do Kowla i tutaj utknęła, bowiem dalej, w kierunku Brześcia Litewskiego, biegł tylko tor normalny. Został on „przeszyty” na szeroki przez 7 kompanię kolejową i dzięki temu pociągi odjechały do Brześcia, a stamtąd - również torem pospiesznie "przeszytym” przez kompanie kolejowe i kolejarzy - do Dęblina. Podobną drogę odbył tabor „szeroki” ewakuowany przez Dyrekcję Wileńską. Dojechał do Baranowicz, tutaj musiał czekać, aż kolejarze i kompanie kolejowe „przeszyją" tor prowadzący do Brześcia na szeroki, i odjechał przez Brześć do Dęblina. Na dęblińskiej stacji zgromadzono ogromny tabor szerokotorowy: 201 parowozów, 379 wagonów osobowych, 6029 towarowych. Łącznie $\mathrm{z}$ taborem ewakuowanym do Lwowa daje to 221

${ }^{56}$ CAW-WBH, Dowództwo Frontu Południowo-Wschodniego, sygn. I.310.7.29, /NDWP Szef kolejnictwa polowego/, Organizacja szefostw kolejowych frontów i armii, b.m. 8 VIII 1920 r., b.p.

${ }^{57}$ A. Szychowski, Wojska kolejowe i ich zadania w ubiegłej wojnie polsko-bolszewickiej (1918-1920), cz. 3, „Bellona” 1922, t. VI, z. 1, s. 277.

${ }^{58}$ Usterki techniczne dotkliwie gnębiły polskie kolejnictwo. Były spowodowane intensywną eksploatacją taboru, niedostateczną liczbą wyszkolonego personelu i części zamiennych. Pewną orientację w skali problemu oddają dane z 1921 r., kiedy dokonano przeglądu sprzętu. $42 \%$ parowozów, 27,4\% wagonów osobowych i 18,2\% towarowych zostało wyłączonych z ruchu i oddanych do remontu, zob. A. Szychowski, Koleje wojskowe w ubiegłej wojnie (1918-1921), „Bellona” 1922, t. VII, z. 2, s. 163, tab. XXX. Uprawnione wydaje się przypuszczenie, że podczas wojny, na skutek intensywnej eksploatacji sprzętu, a zarazem ograniczeń w funkcjonowaniu kolejowych warsztatów naprawczych, odsetek wagonów uszkodzonych lub wymagających pilnie przeglądu był jeszcze wyższy. 
parowozów i ponad 7700 wagonów ${ }^{59}$. Taboru tego użyto we wrześniu 1920 r. między innymi podczas przygotowań do bitwy nad Niemnem.

Straty w taborze szerokotorowym, poniesione podczas odwrotu, sięgnęły ok. 23\%. Część spowodowana była słabym stanem technicznym parowozów i wagonów, które trzeba było zostawić, ponieważ nie nadawały się do jazdy. Sporo sprzętu utracono na Ukrainie we wspomnianym wyżej zatorze kolejowym pod Szepietówką ${ }^{60}$.

Badania nad kolejnictwem polskim doby wojen o niepodległość i granice (1918-1920) wskazują, że w sierpniu 1920 r. koleje pracowały na granicy swojej wydolności, realizując równocześnie zadania związane z ewakuacją, zaopatrywaniem frontu, przewozem wojsk do miejsc koncentracji oraz obsługą najbardziej niezbędnych przewozów wewnątrz kraju. Dysponowały wówczas około 65 tys. wagonów towarowych, nie licząc ewakuowanego taboru szerokotorowego. Trudna do określenia liczba wagonów znajdowała się w naprawach i przeglądach. W tej sytuacji brak kilkunastu tysięcy wagonów ocalonych z zatoru w Białymstoku i w innych miejscach na szlakach odwrotu mógł oznaczać katastrofę komunikacyjną. To zaś prawdopodobnie uniemożliwiłoby terminowe zakończenie koncentracji wojsk nad Wieprzem oraz nadesłanie im niezbędnych uzupełnień i zaopatrzenia.

Tabor szerokotorowy, który przywiózł sporo ewakuowanego ze wschodu mienia wojskowego i zapasów, między innymi amunicji, nie mógł być wykorzystany do przewozu ludzi i zaopatrzenia podczas bitwy nad Wisłą. Przydał się natomiast w ostatnich miesiącach wojny, kiedy prowadzono przegrupowanie wojsk polskich do bitwy nad Niemnem ${ }^{61}$.

Sporym problemem, jaki pojawił się pod koniec lipca, były zatory powodowane przez jadące na zachód masy wojskowych i cywilnych transportów ewakuacyjnych. Kwestia utrzymania płynności ruchu kolejowego stała się wówczas sprawą pierwszorzędnej wagi dla walczącej armii. W instrukcji wydanej 1 sierpnia przez NDWP nakazano całą sieć kolejową na wschód od Wisły bezwzględnie oczyścić z transportów ewakuacyjnych, zaprzestać ewakuacji zdobyczy wojennej, z wyjątkiem najcenniejszej, bezwzględnie opróżniać wagony nawet $\mathrm{z}$ cennego ładunku, jeśli wymagają tego względy operacyjne. Każdy transport kolejowy, z wyjątkiem czołówek kolejowych, pociągów amunicyjnych i tranzytowych, miał być niezwłocznie rozładowany

\footnotetext{
${ }^{59}$ A. Szychowski, Wojska kolejowe..., s. 276.

${ }^{60}$ Stracono ponadto 50 parowozów i 232 wagony wąskotorowe używane głównie do lokalnych połączeń na obszarze operacyjnym. Był to przeważnie sprzęt z czasów wojny światowej, mocno wyeksploatowany.

${ }^{61}$ Jeszcze w trakcie bitwy nad Wisłą NDWP nakazało odszukanie wśród masy taboru szerokotorowego wagonów z ładunkiem amunicji artyleryjskiej, której brak zaczęto odczuwać w oddziałach polskich z powodu opóźniających się dostaw z zachodu.
} 
pod osobistą odpowiedzialnością sądowo-karną dowódcy transportu i przedstawiciela władz kolei. Absolutne pierwszeństwo miały transporty operacyjne ${ }^{62}$.

\section{Zakończenie}

Podsumowując efekty ewakuacji prowadzonej podczas odwrotu armii polskiej w czerwcu, lipcu i pierwszej połowie sierpnia 1920 r., należy stwierdzić, że władze wojskowe i kolejowe zdołały ewakuować z ziem zajmowanych przez Armię Czerwoną niemal cały tabor normalnotorowy i większość szerokotorowego. Uratowano także większość sprzętu wojskowego i zapasów złożonych w magazynach etapowych. Przewieziono do centrum kraju trudną do określenia, ale idącą $\mathrm{w}$ dziesiątki tysięcy liczbę uchodźców cywilnych, jak również większość polskiego personelu kolejowego. Równocześnie, w trakcie ewakuacji, dokonano rozległych zniszczeń na stacjach i liniach kolejowych, których przeciwnik nie potrafił usunąć w krótkim czasie. W dobie bitwy nad Wisłą transport kolejowy dla wojsk Tuchaczewskiego dochodził zasadniczo do Niemna i Bugu. Dalszy przewóz zaopatrzenia w kierunku frontu z konieczności musiał opierać się głównie na powolnym taborze konnym.

Na Ukrainie do końca lipca bolszewicy nie zdołali naprawić wielu wysadzonych przez Polaków mostów kolejowych. Nie przywrócono ruchu na liniach Berdyczów-Szepietówka i Korosteń-Maniewicze, a linia Kijów-Korosteń używana była w ograniczonym zakresie. Odbudowę ważnego mostu na Teterewie pod Cudnowem, naprawionego, a następnie zniszczonego przez polską 7 kompanię kolejową, ukończono dopiero na przełomie lipca i sierpnia. Dla nieprzyjaciela ograniczenia w funkcjonowaniu taboru kolejowego miały między innymi ten skutek, że podczas bitwy nad Wisłą szybko kurczyły się zapasy amunicji, zwłaszcza artyleryjskiej ${ }^{63}$.

W trakcie kontrofensywy znad Wieprza i pościgu za uchodzącymi oddziałami Armii Czerwonej, strona polska, dzięki ofiarności i fachowemu przygotowaniu personelu kolejowego, dobrej organizacji pracy i przemyślanej metodzie dokonywania zniszczeń podczas niedawnej ewakuacji, potrafiła szybko uruchamiać połączenia kolejowe i telegraficzne. Pozwoliło to na wykorzystanie transportu kolejowego do przewozu części wojsk i zaopatrzenia oraz przyczyniło się do utrzymania wysokiego tempa pościgu za oddziałami Armii Czerwonej w ostatniej fazie bitwy nad Wisłą. Zdolność do szybkiej naprawy linii kolejowych oraz fakt uratowania większości taboru kolejowego w trakcie ewakuacji bez wątpienia pomogły dowództwu polskiemu

\footnotetext{
${ }^{62}$ CAW-WBH, Dowództwo 6 Armii, sygn. I.311.6.223, /Dowództwo 6 Armii, Oddział IV/ Operacyjny rozkaz zaopatrzenia nr 34 z 2 VIII 1920 r., b.m., b.p.

${ }^{63}$ Dow. Frontu Płd-Wsch. 30 VII 1920 r., Stan kolejnictwa [w:] Bitwa lwowska 25 VII18 X 1920. Dokumenty operacyjne, cz. 1: 25 VII - 5 VIII, oprac. zesp. pod kier. M. Tarczyńskiego, Warszawa 2002, s. 858-859.
} 
w przygotowaniach do bitwy nad Niemnem i wygraniu „wyścigu czasu” z Tuchaczewskim, szykującym jesienią 1920 r. kolejną ofensywę na Warszawę.

Odwrót wojsk polskich latem 1920 r. nazywamy „wielkim odwrotem”. Towarzyszyła mu ewakuacja, którą ze względu na rozmiary, wielkość użytych środków i czas trwania mamy prawo nazwać „wielką ewakuacją”. Jej sukces ułatwił stronie polskiej przygotowanie kontrofensywy znad Wieprza i dalsze prowadzenie wojny w dwóch ogromnie ważnych aspektach: szybkiego transportu wojsk i zaopatrywania walczących oddziałów. Dlatego pożądane wydaje się lepsze naświetlenie w polskiej literaturze naukowej i popularnonaukowej szeregu kwestii związanych $\mathrm{z}$ ewakuacją, między innymi bliższe ustalenie ilości i rodzaju uratowanych zapasów oraz rozmiaru zniszczeń dokonywanych na szlakach odwrotu, które musiały utrudniać działania przeciwnika. Należałoby pod tym kątem przebadać stosunkowo obfite zespoły akt formacji etapowych oraz rękopisów przechowywane w zbiorach Centralnym Archiwum Wojskowym Wojskowego Biura Historycznego, jak również zachowane materiały i sprawozdania kolejnictwa.

Bardzo słabo przebadano zagadnienie ewakuacji cywilnej. Szacowano, że z ziem pozostających pod zarządem cywilnym ewakuowano około 150 tys. osób, z Podola ok. 50 tys., z Galicji Wschodniej 100 tys., ze wschodnich terenów „Królestwa” ok. 200 tys. Do tych liczb należałoby dodać uchodźców z Ukrainy. Są to liczby orientacyjne. Przy stale przesuwającym się froncie, przygotowaniach do obrony, wielkim ruchu transportów nie prowadzono dokładnej ewidencji ewakuowanych. Ewakuacja objęła prawdopodobnie ponad pół miliona osób. Opisy jej przebiegu i warunków, w jakich się odbywała, można odnaleźć w literaturze pamiętnikarskiej oraz na łamach ówczesnej prasy. Latem 1920 r. pisały o tym m.in. „Gazeta Warszawska”, „Kurier Warszawski”, „Czas”, „Przewodnik Katolicki”, „Tygodnik Ilustrowany”. O tym, jak wyglądały warunki ewakuacji, czy raczej ucieczki setek tysięcy ludzi przez bolszewicką „wolnością”, daje wyobrażenie fragment pamiętnika szwoleżera Tadeusza Szmurły, który opisał kolumny uchodźców towarzyszące cofającemu się wojsku:

„Między maszerującymi masami idą lub jadą na wozach, wypchanych pościelą, dziećmi zdrowymi i chorymi - uciekinierzy. Na kłonicach wozów pozawieszane garnki: obok wozów idą przywiązane, zmęczone i opierające się krowy. [...] Między uciekinierami widać dużo drobnych dzieci, które zmęczone długą podróżą przeważnie śpią; na ich umorusanych i rozespanych twarzyczkach igra słońce, osuszając pozostałe na buziach po śniadaniu resztki kaszy lub okruszyny chleba. Widzi się także ludzi starych, chorych, którzy obłożeni poduszkami leżą na wozach nieruchomo - uciekają zdaje się tylko po to, aby za chwilę umrzeć. [...] Znowu niewesoła 
scena. Oto bokiem szosy młoda, chuda kobieta popycha ręczny dziecięcy wózek, pleciony z wikliny wózek, a w ekwipażu tym siedzą naprzeciw siebie dwa maleństwa. Jedno, może roczne, o blond włoskach i czarnych oczkach - chyba dziewczynka - wesoło się uśmiecha - o mało nie wyleci z jej buzi pusty, żółty gumowy smoczek; siedzący naprzeciw niej, pewno dwuletni braciszek, zacisnął w piąstce zielone, niedojrzałe jabłko i szczerząc małe jak u lalki ząbki, potrząsa zamaszyście rączką.

Po chwili kobieta, dzieci i wózek zostają ulokowane na dużym, niemieckim wozie. Dzieci jadą w swoim własnym wózku, a przy nich pełnią «wartę» i rolę nianiek dwaj lekko ranni poznaniacy. [...] Matka siedzi obok starszego wiekiem, poważnego żołnierza; ciężko dysząc odpoczywa; odwraca się często, aby spojrzeć i uśmiechnąć się przez łzy do swoich pociech, które czują się znakomicie pod troskliwą opieką żołnierzy. Mąż kobiety został przed kilku tygodniami rozstrzelany w Bobrujsku przez bolszewików"64.

Uchodźcy z Podola i Wołynia kierowani byli na Pomorze i do Wielkopolski, a także na ziemię łódzką i kielecczyznę. Na obszar byłego zaboru pruskiego i do Częstochowy ewakuowano około 15 tys. dzieci polskich z przytułków i ochronek. Uchodźcy z terenów między Wisłą a Bugiem znaleźli schronienie na terenach województw warszawskiego, kieleckiego i łódzkiego. Z pomocą uchodźcom wojennym pospieszyły Amerykański Wydział Ratunkowy, Young Men’s Christian Association (Związek Chrześcijańskiej Młodzieży Męskiej), władze samorządowe i państwowe, organizacje społeczne. Przebieg ewakuacji cywilnej przygotowanej przez władze cywilne i powiązanej z ewakuowaniem zapasów (m.in. latem 1920 r. wywieziono z kresów wschodnich 9,2 tys. ton żywności i odzieży przeznaczonej dla ewakuowanych dzieci) ${ }^{65}$, ale często także samorzutnej, żywiołowej oraz formy i zakres pomocy udzielonej uchodźcom, to kolejne tematy wojny Polski z Rosją bolszewicką czekające na pióro historyka.

${ }^{64}$ T. Szmurło, Odwrót [w:] Szwoleżery furażery, Warszawa 1939, s. 115-117.

65 „Gazeta Warszawska”, 2 IX 1920, nr 235. 


\section{Bibliografia}

\section{Archiwalia}

Centralne Archiwum Wojskowe Wojskowego Biura Historycznego

Dowództwo 1 Armii

Dowództwo 4 Armii

Dowództwo 6 Armii

Dowództwo 7 Armii

Dowództwo Etapów Wojska Polskiego Lwów

Dowództwo Etapów Wojska Polskiego na Ukrainie

Dowództwo Frontu Litewsko-Białoruskiego

Dowództwo Frontu Południowego

Dowództwo Frontu Południowo-Wschodniego

Dowództwo Frontu Północno-Wschodniego

Dowództwo Frontu Wołyńskiego

Dowództwo Okręgu Etapowego Kowel

Dowództwo Okręgu Etapowego Podole

Dowództwo Okręgu Etapowego Tarnopol

Kolekcja rękopisów

Oddział IV Naczelnego Dowództwa Wojska Polskiego

Wołyńska Inspekcja Etapowa

\section{Źródła drukowane}

Bitwa lwowska 25 VII-18 X 1920. Dokumenty operacyjne, cz. 1: 25 VII - 5 VIII, oprac. zesp. pod kier. M. Tarczyńskiego, Warszawa 2002.

O niepodległa i granice, t. 8: Raporty Straży Kresowej 1919-1920 Ziem Północno-Wschodnich opisanie, oprac. J. Gierowska-Kałłaur, Warszawa-Pułtusk 2011. Sprawozdanie z działalności Dyrekcji Kolei Państwowych $w$ Warszawie 1918-1928, Warszawa 1928.

\section{Opracowania}

Borkiewicz A., Dzieje 1-go pułku piechoty Legionów, Warszawa 1929.

Burnagel S., Wspomnienia wojenne intendenta dywizji, Warszawa 1934.

Burnagel S., Ze wspomnień wojennych intendenta dywizji, „Przegląd Intendencki” 1931, z. 3.

Dec S., Intendentura 7-ej dywizji piechoty w wojnie o wywalczenie granic Polski. Szkic historyczno-taktyczny z zakresu operacyjnej służby sztabów, Warszawa 1934.

Grzegorczyk T., 6 Armia Wojska Polskiego w 1920 r., Toruń 2009.

Lis-Błoński S., Pięćdziesiąt dni na Podolu w 1920 r., „Niepodległość” 1939, t. XX, Z. 2 (55).

Michalczyk W., Zarys historii wojennej 1-go pułku saperów kolejowych, Warszawa 1931. 
Odziemkowski J., Obrona Drohobycko-Borysławskiego Zagłębia Naftowego przez wojska polskie i ukraińskie w sierpniu 1920 roku, „Studia i Materiały Centralnej Biblioteki Wojskowej im. Marszałka Józefa Piłsudskiego” 2014, nr 1.

Odziemkowski J., Polskie formacje etapowe na Litwie i Białorusi 1919-1920, Kraków 2011.

Odziemkowski J., Polskie formacje etapowe w Galicji Wschodniej, na Wołyniu i Ukrainie w latach 1918-1920, Warszawa 2019.

Odziemkowski J., Polskie kolejnictwo wojskowe na froncie wschodnim 1918-1920, Kraków 2011.

Odziemkowski J., Wojska samochodowe - niedoceniany czynnik polskiego zwycięstwa w 1920 roku [w:] Bitwa Warszawska 1920 roku. w obronie niepodległości, red. J. Odziemkowski, Warszawa 2006.

Odziemkowski J., Żołnierze z kresów północno-wschodnich w obronie Warszawy, sierpień 1920, Brzeście 2014.

Polskie Koleje Państwowe 1918-1929, Warszawa 1929.

Протопопов А., Отход 3 польской армии от Киева в июне 1920 года, „Война и революция" 1929, nr 7-8.

Romer J. E., Pamiętniki, Warszawa 2010.

Rostworowski A., Ziemia, której już nie zobaczysz, Warszawa 2001.

Skrzetelski T., Polskie koleje Państwowe [w:] Dziesięciolecie Polski Niepodległej, Warszawa 1928.

Studia taktyczne z historii wojen polskich 1918-21, t. V: Manewr na Mozyrz i Kalinkowicze 4 III-12 III 1920 r., oprac. J. Ciałowicz, Warszawa 1925.

Szmurło T., Odwrót [w:] Szwoleżery furażery, Warszawa 1939.

Szychowski A., Koleje wojskowe w ubiegłej wojnie (1918-1921), „Bellona” 1922, t. VII, z. 2 .

Szychowski A., Wojska kolejowe i ich zadania w ubiegłej wojnie polsko-bolszewickiej (1918-1920), cz. 3, „Bellona” 1922, t. VI, z. 1.

Wyporek J., Zarys historii wojennej 2-go pułku wojsk kolejowych, Warszawa 1930.

Prasa

„Gazeta Warszawska”, 2 IX 1920, nr 235.

\section{STRESZCZENIE}

\section{Janusz Odziemkowski, Ewakuacja podczas odwrotu wojsk polskich w okresie czerwiec-sierpień 1920 roku - wybrane zagadnienia}

Dowództwo polskie już wiosną 1919 r., w związku z groźbą inwazji niemieckiej, stanęło przed koniecznością przygotowania planu ewakuacji z zajętych terenów Litwy i Białorusi. Kolejne plany powstające w okresie sukcesów wojsk polskich i marszu na wschód przewidywały ewakuację niewielkich obszarów na zagrożonych odcinkach frontu. Pierwsza ofensywa Michaiła Tuchaczewskiego w maju 1920 r. obnażyła niedostatki polskich planów ewakuacyjnych, m.in. braki taboru kolejowego, 
szwankującą łączność, niedostateczną współpracę z władzami cywilnymi, samorzutną, trudną do opanowania ewakuację ludności i administracji państwowej.

Zebrane doświadczenia pozwoliły przygotować bardziej precyzyjną instrukcję ewakuacyjną. Nikt jednak nie przewidział rozmiarów ewakuacji, jaką trzeba było przeprowadzić latem 1920 r. Kierownictwo nad nią sprawowały władze wojskowe. Objęła zaplecze całego frontu od Łotwy po granicę z Rumunią. Wiązała się z koniecznością przewozu ładunków i ludzi na odległość 400-600km w głąb kraju. Przebiegała w warunkach stałego nacisku nieprzyjaciela, zwłaszcza na północnym odcinku frontu. Oparta była głównie na kolei, jedynym wówczas szybkim i pojemnym środku transportu.

Mimo ekstremalnie trudnych warunków i nieuniknionych przypadków chaosu ocalono masę cennego sprzętu, zapasów, ewakuowano dziesiątki tysięcy rannych oraz uchodźców i cenny tabor kolejowy niezbędny dla pomyślnego przeprowadzenia przegrupowania wojsk do kontrofensywy znad Wieprza.

Słowa kluczowe: wojna polsko-bolszewicka, ewakuacja przymusowa, ewakuacja planowa, instrukcja ewakuacyjna, strefa ewakuacyjna, centra ewakuacyjne, tabor kolejowy, obszar etapowy, odwrót, transport ewakuacyjny, ludność cywilna, zniszczenia, chaos

\section{SUMMARY}

\section{Janusz Odziemkowski, Evacuation during the Retreat of Polish Troops in June-August 1920 - Selected Issues}

Already in the spring of 1919, due to the threat of a German invasion, the Polish command had to prepare a plan of evacuation from the occupied territories of Lithuania and Belarus. Subsequent plans, prepared during the period of success of the Polish troops and the march to the east, assumed evacuation of small areas on endangered sections of the front. Tukhachevsky's first offensive in May 1920 revealed the deficiencies of Polish evacuation plans, such as lack of rolling stock, poor communication, insufficient cooperation with civil authorities, a spontaneous and barely controllable evacuation of civil population and state administration.

The experience gathered allowed to prepare more precise evacuation instructions. No one, however, predicted the scale of the evacuation that had to be carried out in summer 1920. It was managed by the military authorities. It was supervised by military authorities and covered the entire front line from Latvia to the border with Romania. It involved the transportation of cargo and people $400-600 \mathrm{~km}$ into the country and took place under constant enemy pressure, especially in the northern section of the front. It was based mainly on railroads, the only fast and capacious means of transport at that time.

Despite extremely difficult conditions and inevitable chaos, a lot of valuable equipment and supplies were saved, tens of thousands of injured people and refugees were evacuated, as well as valuable rolling stock necessary for the successful regrouping of troops for the Wieprz counteroffensive. 
Keywords: Polish-Soviet War, enforced evacuation, planned evacuation, evacuation instructions, evacuation zone, evacuation centers, rolling stock, rear area, retreat, evacuation transportation, civil population, damages, chaos

\section{АННОТАЦИЯ \\ Януш Одземковский, Эвакуация при отступлении польских войск в июне-августе 1920 г. Избранные вопросы}

Еще весной 1919 г. из-за угрозы немецкого вторжения у Верховного командования польской армии возникла необходимость подготовить план эвакуации с оккупированных территорий Литвы и Белоруссии. Последующие планы, разработанные в период успеха польской армии и продвижения на восток, предусматривали эвакуацию небольших участков фронта, находящихся в опасном положении. Первое наступление Тухачевского в мае 1920 г. выявило недостатки польских планов эвакуации, в том числе недостаточное оснащение железных дорог, неисправности связи, недостаточное взаимодействие с гражданскими властями, стихийную, трудно контролируемую эвакуацию населения и государственной администрации.

Полученный опыт позволил составить более точную инструкцию по эвакуации. Однако никто не предвидел масштабы эвакуации, которую необходимо было провести летом 1920 года. Руководили ею военные власти. Эвакуация проходила по территориям, связанным практическим со всем фронтом от Латвии до границы с Румынией. Это было продиктовано необходимостью перевозки грузов и людей на 400-600 км вглубь страны. Эвакуация проходила под постоянным натиском противника, особенно на северном участке фронта, и, в основном, с помощью поездов - единственного в то время быстрого и вместительного транспортного средства. Несмотря на чрезвычайно тяжелые условия и неизбежные ситуации хаоса, было спасено много ценного оборудования и припасов, эвакуированы десятки тысяч раненых и беженцев, а также ценные в той ситуации поездные составы, необходимые для успешного проведения перегруппировки войск для контрнаступления со стороны реки Вепш.

Ключевые слова: польско-большевистская война, принудительная эвакуация, плановая эвакуация, инструкции по эвакуации, зона эвакуации, центры эвакуации, поездные составы, плацдарм, отступление, эвакуационный транспорт, гражданское население, разрушения, хаос 